\title{
Organic sensitizers bearing a trialkylsilyl ether group for liquid dye sensitized solar cells
}

\author{
Raquel Pẻrez-Tejada ${ }^{\text {a }}$, Natalia Martínez de Baroja ${ }^{\text {a }}$, Santiago Franco ${ }^{\text {a, }}$, Laia Pelleja ${ }^{\text {b, ***, }}$ \\ Jesús Orduna ${ }^{a}$, Raquel Andreu a, Javier Garín ${ }^{a}$ \\ ${ }^{a}$ Departamento de Química Orgảnica, Instituto de Ciencia de Materiales de Aragón (ICMA), Universidad de Zaragoza e CSIC, E50009 Zaragoza, Spain \\ ${ }^{\mathrm{b}}$ Institute of Chemical Research of Catalonia (ICIQ), Avda Països Catalans 16, Tarragona E-43007, Spain
}

\section{a b s t r a c t}

In this work we present the synthesis, optical characterization and performance of five metal-free sensitizers for dye-sensitized solar cells (DSSC). All dyes include, for the first time, a trialkylsilyl ether group in the p-conjugated bridge (a thiophene ring). The influence of different donor unities, like tri- arylamine (TPA), 4H-pyranylidene and dithiafulvene has been evaluated in DSSC with a liquid $\mathrm{I}_{3} / \mathrm{I}^{-}$electrolyte, obtaining the best results with the $4 \mathrm{H}$-pyranylidene moiety. The size and the position of the bulky group have a great importance in the efficiency of the final devices.

In order to explain the recombination processes and electron life-time, charge extraction (CE) and transient photovoltage (TPV) experiments have been carried out.

\section{Introduction}

Solar energy offers a clean, well-spread and inexhaustible energy source. Although the market is dominated by silicon-based photovoltaic devices, in recent years the interest on alternatives more environment-friendly has increased, specially focused on reducing mass during cell manufacture processes and the thickness of the final device.

Organic Photovoltaic Cells (OPVs) [1,2] and particularly Dye Sensitized Solar Cells (DSSCs) [3,4] constitute an interesting alternative due to their low manufacturing cost, flexibility of molecular design, light-weight and great esthetic features, like color and transparency. The key element in a DSSC device is probably the sensitizer dye and over the last years, thousands of new dyes have been investigated. The most efficient organic sensitizers are based on Donorep spacereacceptor (DepeA) structures [5], a type of pushepull systems which lead to effective photoinduced intramolecular charge-transfer (ICT). In these systems small variations in the different parts of the molecule (mostly in the donor and the p-bridge) may result in significant changes in the photovoltaic properties. Triphenylamine (TPA)-based metal free organic dyes are one of the most common donor groups in DSSCs [6,7], as it presents several advantages, like a non-planar structure, which suppresses the formation of aggregates. Furthermore, the physical properties can be easily modulated by introduction of bulky or donor groups [8e13]. Recently, proaromatic systems like 4H-pyranylidene [14e17] and dithiafulvene [18e20] have been introduced as alternative and efficient donor unities in DSSCs, but no studies comparing their properties have been reported.

When designing a new sensitizer, one important factor to take into account is related to the minimization of aggregates by pep stacking. This may be performed by using additives, such as deoxycholic acid (DCA) [21,22] or by the introduction of bulky groups both, in the donor or in the p-bridge [12,23e26]. However, it is relatively difficult to synthesize dyes with bulky chains in the conjugated spacer, requiring tedious and multiple reaction steps.

Silicon-based dyes have been very promising for DSSCs due to its photo and thermal stability [27,28]. Examples of organic sensitizers bearing a dithienosilole (DTS) as a p-linker have been reported with high efficiencies [29e34]. However, to the best of our knowledge, organic dyes featuring a trialkylsilyl ether 


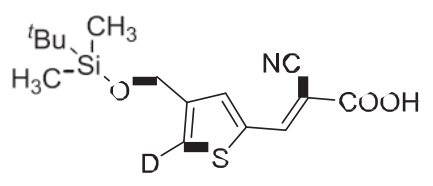

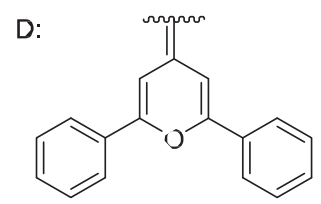

$4 H-P y r$

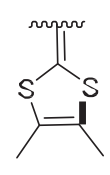

1,3-DT

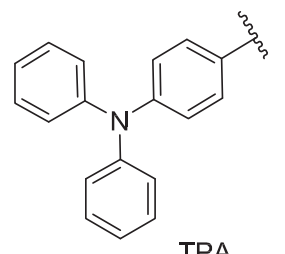

TPA
Fig. 1. Molecular structures of TBDMS organic sensitizers.<smiles>[R]c1c(C=C2C=C(c3ccccc3)OC(c3ccccc3)=C2)sc(C=C(C)C(=O)O)c1[R2]</smiles>

$\mathrm{R}_{1}=\mathrm{CH}_{2} \mathrm{OTBDPS}$ or $\mathrm{CH}_{2} \mathrm{OTBDMS}, \mathrm{R}_{2}=\mathrm{H}$

$\mathrm{R}_{1}=\mathrm{H}, \mathrm{R}_{2}=\mathrm{CH}_{2} \mathrm{OTBDPS}$

Fig. 2. Molecular structures of 4H-pyranylidene organic sensitizers.

$\left(\mathrm{R}_{1} \mathrm{R}_{2} \mathrm{R}_{3} \mathrm{SiO}-\right)$ were never used to preclude the p-aggregation on the $\mathrm{TiO}_{2}$ in DSSCs. This popular protecting group can be easily introduced from alcohols [35] and the overall size and the stability depend on the nature of the $R_{1}, R_{2}$ or $R_{3}$. Moreover, the silyl ether group greatly enhances the solubility of the sensitizer that facilitates its adsorption on the $\mathrm{TiO}_{2}$ surface.

In the present work, a series of five new metal-free organic sensitizers for DSSCs with a trialkylsilyloxy group have been designed, synthesized and characterized. In order to evaluate the donor influence on the photovoltaic properties a TPA and two proaromatic donor unities (4H-pyranylidene and dithiafulvene) have been used (Fig. 1).

The influence of the size and the relative position on the heterocyclic linker of two bulky groups, tert-butyldimethyl (TBDMS) or tert-butyldiphenyl silyl ether (TBDPS) is also studied (Fig. 2). Finally, the photophysical properties, molecular orbital calculations and the performance of DSSCs based on these organic dyes are reported.

\section{Experimental section}

\subsection{General information}

Infrared measurements were carried out in $\mathrm{KBr}$ or neat using a PerkineElmer Fourier Transform Infrared 1600 spectrometer. Melting points were obtained on a Gallenkamp apparatus in open capillaries and are uncorrected. ${ }^{1} \mathrm{H}$ and ${ }^{13} \mathrm{C}$ NMR spectra were recorded on a Bruker ARX300 or a Bruker AV400 at 300 or $400 \mathrm{MHz}$ and 75 or $100 \mathrm{MHz}$ respectively; d values are given in ppm (relative to TMS) and J values in $\mathrm{Hz}$. The apparent resonance multiplicity is described as s (singlet), d (doublet), and m (multiplet). ${ }^{1} \mathrm{He}^{1} \mathrm{H}$ COSY and ${ }^{1} \mathrm{He}^{13} \mathrm{C}$-HSQC experiments were recorded on a Bruker ARX300 or a Bruker AV400 at 300 or $400 \mathrm{MHz}$ in order to establish peaks assignment and spatial relationships. Electrospray mass spectra were recorded on a Bruker Microtof-Q spectrometer; accurate mass measurements were achieved using sodium formate as external reference. UVeVisible spectra were recorded with a UVeVis UNICAM UV4 spectrophotometer. Pulse differential voltammetry measurements were performed with a m-Autolab type III potentiostat using a glassy carbon working electrode, Pt counter electrode, and $\mathrm{Ag} / \mathrm{AgCl}$ reference electrode. The experiments were carried out under argon in $\mathrm{CH}_{2} \mathrm{Cl}_{2}$, with $\mathrm{Bu}_{4} \mathrm{NPF}_{6}$ as supporting electrolyte $\left(0.1 \mathrm{~mol} \mathrm{~L}^{-1}\right)$. Scan rate was $0.01 \mathrm{~V} \mathrm{~s}^{-1}$, modulation amplitude $0.025 \mathrm{~V}$ and modulation time $0.05 \mathrm{~s}^{-1}$.

\subsection{Synthesis}

2.2.1. 4-((tert-Butyldimethylsilyloxy)methyl)-5-((2,6-diphenyl-4Hpyran-4-ylidene)methyl)thiophene-2-carbaldehyde (7)

A solution of 2,6-diphenyl-(4H-pyran-4ylidene)-diphenylphosphine oxide 5 (680 $\mathrm{mg}, 1.56 \mathrm{mmol})$ in anhydrous THF (12 mL) was prepared, purged with argon and cooled to $-78{ }^{\circ} \mathrm{C}$. To this solution, n-BuLi (1.6 $\mathrm{M}$ in hexanes) $(1.2 \mathrm{~mL}, 2.08 \mathrm{mmol})$ was added dropwise and the resulting mixture was stirred for $15 \mathrm{~min}$. Then 3-((tertbutyldimethylsilyloxy)methyl)thiophene-2-carbaldehyde 4 (472 mg; $1.84 \mathrm{mmol})$ in anhydrous THF $(5 \mathrm{~mL})$ was added dropwise and the mixture was warmed to $0{ }^{\circ} \mathrm{C}$ for $3 \mathrm{~h}$ (TLC monitoring using $10 \%$ EtOAc in hexanes). Saturated $\mathrm{NH}_{4} \mathrm{Cl}$ solution was added to quench the reaction and the solvent was evaporated under reduced pressure. The organic layer was extracted with EtOAc $(2 \times 25 \mathrm{~mL})$ and dried over anhydrous $\mathrm{MgSO}_{4}$. After the removal of the solvent, the residue was dissolved in EtOAc/hexanes (3/97) and filtered over silica gel to give the crude tert-butyl((2-((2,6-diphenyl-4H-pyran-4-ylidene)methyl) thiophen-3-yl)methoxy)dimethylsilane 6 as an intermediate. Then, a solution of 2,2,6,6-tetramethylpiperidine $(0.27 \mathrm{mg}, 1.58 \mathrm{mmol})$ in THF $(8.4 \mathrm{~mL})$ was prepared, purged with argon and cooled to $-78^{\circ} \mathrm{C}$. To this solution, ${ }^{\mathrm{t}} \mathrm{BuLi}(1.7 \mathrm{M}$ in pentane) $(1.01 \mathrm{~mL}, 1.71 \mathrm{mmol})$ was added dropwise and the resulting mixture was stirred for $1 \mathrm{~h}$ and then a solution of $6(676.0 \mathrm{mg}, 1.41 \mathrm{mmol})$ in THF $(33.6 \mathrm{~mL})$ was added. The resulting mixture was stirred for an additional hour, DMF $(0.28 \mathrm{~mL}, 3.70 \mathrm{mmol})$ was added dropwise and the mixture was warmed to $-30{ }^{\circ} \mathrm{C}$. The reaction was quenched by the addition of saturated $\mathrm{NH}_{4} \mathrm{Cl}$ solution and the solvent was evaporated under reduced pressure. The organic layer was extracted with EtOAc $(2 \times 20 \mathrm{~mL})$ and dried over anhydrous $\mathrm{MgSO}_{4}$. After the removal of the solvent, the aldehyde 7 was purified by silica gel column chromatography (6\% EtOAc in hexanes). Yield: red oil $(583.0 \mathrm{mg}$, $1.16 \mathrm{mmol} ; 82 \%)$.

IR (neat): $\mathrm{cm}^{-1} 1648$ (C]O), 1573 (C]C). ${ }^{1} \mathrm{H}$ NMR (400 MHz, $\left.\mathrm{CDCl}_{3}\right): \mathrm{d}(\mathrm{ppm}) 9.81(\mathrm{~s}, 1 \mathrm{H}), 7.90 \mathrm{e} 7.76(\mathrm{~m}, 4 \mathrm{H}), 7.69(\mathrm{~s}, 1 \mathrm{H})$, 7.55 e $7.43(\mathrm{~m}, 6 \mathrm{H}), 7.29(\mathrm{~d}, \mathrm{~J} 1 / 42.0 \mathrm{~Hz}, 1 \mathrm{H}), 6.55(\mathrm{~d}, \mathrm{~J} 1 / 42.0 \mathrm{~Hz}, 1 \mathrm{H})$, $6.07 \quad(\mathrm{~s}, 1 \mathrm{H}), 4.75 \quad(\mathrm{~s}, 2 \mathrm{H}), 0.96 \quad(\mathrm{~s}, 9 \mathrm{H}), 0.14 \quad(\mathrm{~s}, 6 \mathrm{H}) .{ }^{13} \mathrm{C} \quad \mathrm{NMR}$ $\left(100 \mathrm{MHz}, \mathrm{CDCl}_{3}\right)$ : d (ppm) 182.1, 155.3, 152.6, 146.6, 139.0, 137.9, 137.0, 132.8, 132.5, 132.5, 130.2, 129.7, 128.9, 128.8, 125.3, 124.7, 109.0, 104.7, 102.9, 59.7, 26.0, 18.4, -5.2. HRMS $\left(\mathrm{ESI}^{\mathrm{b}}\right)$ : $\mathrm{m} / \mathrm{z}$ calcd for $\left[\mathrm{C}_{30} \mathrm{H}_{33} \mathrm{O}_{3} \mathrm{SSi}\right]^{\mathrm{p}}$ : 501.1914, found: $501.1914[\mathrm{M} \mathrm{p} \mathrm{H}]^{\mathrm{p}}$; calcd for $\left[\mathrm{C}_{30} \mathrm{H}_{32} \mathrm{NaO}_{3} \mathrm{SSi}\right]^{\mathrm{p}}:$ 523.1734, found: 523.1721 [M $\left.^{\mathrm{p} \mathrm{Na}}\right]^{\mathrm{p}}$.

2.2.2. 4-((tert-Butyldimethylsilyloxy)methyl)-5-((4,5-dimethyl-1,3dithiol-2ylidene)methyl)thiophene-2-carbaldehyde (10)

A solution of tributyl(4,5-dimethyl-1,3-dithiol-2-yl)phosphonium hexafluorophosphate $8(317.7 \mathrm{mg}, 0.66 \mathrm{mmol})$ and 3-((tert-butyldimethylsilyloxy)methyl)thiophene-2-carbaldehyde $4(131.0 \mathrm{mg}$, $0.51 \mathrm{mmol})$ in anhydrous THF $(16 \mathrm{~mL})$ was prepared, purged with argon and cooled to $-78{ }^{\circ} \mathrm{C}$. To this solution, $\mathrm{Et}_{3} \mathrm{~N}(352.4 \mathrm{~mL}$, $2.51 \mathrm{mmol}$ ) was added dropwise and the resulting mixture was stirred for $15 \mathrm{~min}$. After the removal of the solvent, the residue was dissolved in EtOAc/hexanes (1:9) and filtered over neutral aluminum oxide to give compound 9 as an intermediate. Then, a solution of 9 in THF $(10 \mathrm{~mL})$ was prepared, purged with argon and cooled to $-45^{\circ} \mathrm{C}$. To this solution, $\mathrm{n}$-BuLi (1.6 $\mathrm{M}$ in hexanes) $(0.53 \mathrm{~mL}, 0.85 \mathrm{mmol})$ was 
added dropwise and the resulting mixture was stirred for $1 \mathrm{~h}$. DMF $(0.09 \mathrm{~mL}, 1.2 \mathrm{mmol})$ was added dropwise and then, the mixture was warmed to room temperature over $24 \mathrm{~h}$. Saturated $\mathrm{NH}_{4} \mathrm{Cl}$ solution was added to quench the reaction and the solvent was evaporated under reduced pressure. The organic layer was extracted with $\mathrm{CH}_{2} \mathrm{Cl}_{2}$ and dried over anhydrous $\mathrm{MgSO}_{4}$. After the removal of the solvent, the aldehyde 10 was purified by silica gel column chromatography (20\% ethyl acetate in hexanes). Yield: red oil (136.2 mg, $0.34 \mathrm{mmol} ; 67 \%)$.

IR (neat): $\mathrm{cm}^{-1} 1649$ (C] O), 1492 (C]C). ${ }^{1} \mathrm{H}$ NMR (400 MHz, $\left.\mathrm{CDCl}_{3}\right): \mathrm{d}(\mathrm{ppm}) 9.80(\mathrm{~s}, 1 \mathrm{H}), 7.65(\mathrm{~s}, 1 \mathrm{H}), 6.82(\mathrm{~s}, 1 \mathrm{H}), 4.69(\mathrm{~s}, 2 \mathrm{H})$, $2.09(\mathrm{~s}, 3 \mathrm{H}), 2.03 \quad(\mathrm{~s}, 3 \mathrm{H}), 0.92 \quad(\mathrm{~s}, 9 \mathrm{H}), 0.09 \quad(\mathrm{~s}, 6 \mathrm{H}) .{ }^{13} \mathrm{C} \quad \mathrm{NMR}$ $\left(100 \mathrm{MHz}, \mathrm{CDCl}_{3}\right): \mathrm{d}(\mathrm{ppm}) 181.9,146.6,142.5,137.9,137.3,135.8$, 124.4, 123.4, 102.9, 59.6, 25.9, 18.3, 13.8, 13.1, -5.2. HRMS (ESI $\left.{ }^{\mathrm{p}}\right): \mathrm{m} / \mathrm{z}$ calcd for $\left[\mathrm{C}_{18} \mathrm{H}_{27} \mathrm{O}_{2} \mathrm{~S}_{3} \mathrm{Si}\right]^{\mathrm{p}}$ : 399.0937, found: $399.0961[\mathrm{M} \mathrm{p} \mathrm{H}]^{\mathrm{p}}$; calcd for $\left[\mathrm{C}_{18} \mathrm{H}_{26} \mathrm{NaO}_{2} \mathrm{~S}_{3} \mathrm{Si}\right]^{\mathrm{p}}: 421.0756$, found: $421.0784[\mathrm{M} \mathbf{~} \mathrm{Na}]^{\mathrm{p}}$.

2.2.3. 4-(3-((tert-Butyldimethylsilyloxy)methyl)thiophen-2-yl)$\mathrm{N}, \mathrm{N}$-diphenylaniline (13)

A solution of the stannyl derivative $12(990.0 \mathrm{mg}, 1.87 \mathrm{mmol})$ and compound $11(668.2 \mathrm{mg}, 1.87 \mathrm{mmol})$ in anhydrous toluene $(24 \mathrm{~mL})$ was prepared, purged with argon for $15 \mathrm{~min}$ before addition of $\mathrm{Pd}\left(\mathrm{PPh}_{3}\right)_{4}(112.3 \mathrm{mg}, 0.10 \mathrm{mmol})$. The reaction mixture was refluxed for $15 \mathrm{~h}$ under an argon atmosphere. After addition of water $(30 \mathrm{~mL})$, the mixture was extracted with toluene $(2 \times 30 \mathrm{~mL})$. The organic phase was washed with a saturated aqueous solution of $\mathrm{NH}_{4} \mathrm{Cl}(30 \mathrm{~mL})$ and water $(3 \times 10 \mathrm{~mL})$ and dried over anhydrous $\mathrm{MgSO}_{4}$. After the removal of the solvent, the compound was purified by silica gel column chromatography (2\% diethyl ether in hexanes). Yield: light yellow oil (392.4 $\mathrm{mg}, 0.83 \mathrm{mmol} ; 44 \%)$.

IR (neat): $\mathrm{cm}^{-1} 1592$ (C]C). ${ }^{1} \mathrm{H}$ NMR (300 MHz, $\left.\mathrm{CD}_{2} \mathrm{Cl}_{2}\right)$ : d (ppm) $7.39 \mathrm{e} 7.33(\mathrm{~m}, 2 \mathrm{H}), 7.32 \mathrm{e} 7.24(\mathrm{~m}, 4 \mathrm{H}), 7.21(\mathrm{~d}, \mathrm{~J} 1 / 45.2 \mathrm{~Hz}, 1 \mathrm{H})$, $7.15 \mathrm{e} 7.02$ (m, 9H), 4.68 (s, 2H), 0.89 (s, 9H), 0.05 (s, 6H). ${ }^{13} \mathrm{C}$ NMR (100 MHz, $\left.\mathrm{CD}_{2} \mathrm{Cl}_{2}\right)$ : d (ppm) 148.1, 148.0, 140.6, 137.6, 130.4, 130.3,

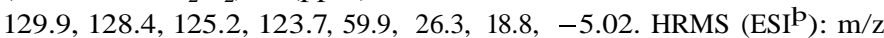
calcd for $\left[\mathrm{C}_{29} \mathrm{H}_{34} \mathrm{NOSSi}^{\mathrm{p}}\right]^{\mathrm{s}}$ : 472.2125, found: $472.2109[\mathrm{M} \mathrm{b} \mathrm{H}]^{\mathrm{p}}$;

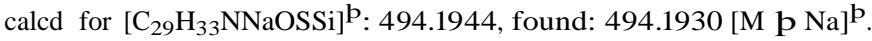

\subsubsection{4-((tert-Butyldimethylsilyloxy)methyl)-5-(4-}

(diphenylamino)phenyl)thiophene-2-carbaldehyde (14)

A solution of 13 (352.4 mg, $0.75 \mathrm{mmol})$ in anhydrous THF $\left(17 \mathrm{~mL}\right.$ ) was prepared, purged with argon and cooled to $-30{ }^{\circ} \mathrm{C}$. To this solution, $\mathrm{n}-\mathrm{BuLi}(1.6 \mathrm{M}$ in hexanes) $(0.78 \mathrm{~mL}, 1.25 \mathrm{mmol})$ was added dropwise and the resulting mixture was stirred for $1 \mathrm{~h}$. Then, DMF (173 $\mathrm{mL}, 2 \mathrm{mmol})$ was added dropwise and the mixture was warmed to room temperature (TLC monitoring using $2 \%$ diethyl ether in hexanes). Saturated $\mathrm{NH}_{4} \mathrm{Cl}$ solution was added to quench the reaction and the solvent was evaporated under reduced pressure. The organic layer was extracted with diethyl ether $(15 \times 3 \mathrm{~mL})$ and dried over anhydrous $\mathrm{MgSO}_{4}$. After removal of the solvent, the aldehyde 14 was purified by column chromatography on silica gel (2\% ethylic ether in hexanes). Yield: yellow oil (298.6 mg, $0.50 \mathrm{mmol} ; 80 \%$ ).

IR (neat): $\mathrm{cm}^{-1} 1670$ (C】O), 1445 (C]C). ${ }^{1} \mathrm{H}$ NMR (400 MHz, $\left.\mathrm{CD}_{2} \mathrm{Cl}_{2}\right): \mathrm{d}(\mathrm{ppm}) 9.84(\mathrm{~s}, 1 \mathrm{H}), 7.80(\mathrm{~s}, 1 \mathrm{H}), 7.41 \mathrm{e} 7.38(\mathrm{~m}, 2 \mathrm{H})$, 7.33e7.29 (m, 4H), 7.16e7.05 (m, 8H), $4.72(\mathrm{~s}, 2 \mathrm{H}), 0.91$ (s, 9H), 0.08 (s, 6H). ${ }^{13} \mathrm{C}$ NMR $\left(100 \mathrm{MHz}, \mathrm{CD}_{2} \mathrm{Cl}_{2}\right)$ : d (ppm) 183.2, 150.3, 149.4, 147.7, 141.0, 139.5, 139.2, 130.4, 130.0, 126.5, 125.7, 124.4, 122.7, 60.0, $26.3,18.8,-4.5$. HRMS $\left(\mathrm{ESI}^{\mathrm{b}}\right): \mathrm{m} / \mathrm{z}$ calcd for $\left[\mathrm{C}_{30} \mathrm{H}_{34} \mathrm{NO}_{2} \mathrm{SSi}\right]^{\mathrm{b}}$ : 500.2074 , found: $500.2045[\mathrm{M} \mathrm{p} \mathrm{H}]^{\mathrm{p}}$.

\subsubsection{3-(4-((tert-Butyldimethylsilyloxy)methyl)-5-((2,6-diphenyl-} 4H-pyran-4-ylidene)methyl) thiophen-2-yl)-2-cyanoacrylic acid (1)

To a solution of aldehyde $7(122 \mathrm{mg}, 0.24 \mathrm{mmol})$ and 2cyanoacetic acid (33 $\mathrm{mg}, 0.38 \mathrm{mmol})$ in chloroform $(5 \mathrm{~mL})$ was added piperidine $(160 \mathrm{~mL} ; 1.62 \mathrm{mmol})$. The mixture was refluxed for
$24 \mathrm{~h}$ under an argon atmosphere and then cooled down to room temperature. $\mathrm{HCl}(1 \mathrm{~N})$ was added until $\mathrm{pH} 1 / 43$, the organic phase was dried over $\mathrm{MgSO}_{4}$ and concentrated under reduced pressure. Then, hexane was added and a solid appeared. This compound was filtered under reduced pressure and washed with a mixture hexane/ $\mathrm{CH}_{2} \mathrm{Cl}_{2}(9 / 1)$ to afford 1 Yield: dark purple solid (134 mg, $0.24 \mathrm{mmol} ; 96 \%)$.

$\mathrm{Mp} 215 \mathrm{e} 218{ }^{\circ} \mathrm{C} . \mathrm{IR}(\mathrm{KBr}): \mathrm{cm}^{-1} 3100 \mathrm{e} 2600(\mathrm{COOeH}), 2210$ $(\mathrm{C} \wedge \mathrm{N}), 1672$ (C J O), 1652 (C IC). ${ }^{1} \mathrm{H}$ NMR (400 MHz, dmso-d 6 ): d (ppm) $8.33(\mathrm{~s}, 1 \mathrm{H}), 8.02 \mathrm{e} 7.89(\mathrm{~m}, 4 \mathrm{H}), 7.86(\mathrm{~s}, 1 \mathrm{H}), 7.63 \mathrm{e} 7.45(\mathrm{~m}$, 6H), $7.37(\mathrm{~d}, \mathrm{~J} 1 / 41.5 \mathrm{~Hz}, 1 \mathrm{H}), 7.11(\mathrm{~d}, \mathrm{~J} 1 / 41.5 \mathrm{~Hz}, 1 \mathrm{H}), 6.37$ (s, 1H), 4.76 $(\mathrm{s}, 2 \mathrm{H}), 0.90(\mathrm{~s}, 9 \mathrm{H}), 0.11 \quad(\mathrm{~s}, 6 \mathrm{H}) .{ }^{13} \mathrm{C}$ NMR $\left(75 \mathrm{MHz}\right.$, dmso-d $\left._{6}\right)$ : d (ppm) 164.1, 154.8, 151.9, 145.7, 144.9, 139.3, 132.2, 131.6, 131.5, 130.5, 130.0, 129.9, 129.1, 128.9, 124.8, 124.5, 117.7, 109.1, 105.3, 102.4, 58.7, 25.7, 17.9, -5.4. HRMS $\left(\mathrm{ESI}^{\mathrm{p}}\right): \mathrm{m} / \mathrm{z}$ calcd for $\left[\mathrm{C}_{33} \mathrm{H}_{34} \mathrm{NO}_{4} \mathrm{SSi}\right]^{\mathrm{p}}$ : 568.1972, found: 568.1945 [M p H] $^{\mathrm{b}}$.

2.2.6. 3-(4-((tert-Butyldimethylsilyloxy)methyl)-5-((4,5-dimethyl1,3-dithiol-2-ylidene)methyl)thiophen-2-yl)-2-cyanoacrylic acid (2)

To a solution of aldehyde $10(136.4 \mathrm{mg}, 0.34 \mathrm{mmol})$ and 2cyanoacetic acid (45.4 mg, $0.53 \mathrm{mmol})$ in chloroform $(32 \mathrm{~mL})$ was added piperidine $(226.4 \mathrm{~mL}, 2.25 \mathrm{mmol})$. The mixture was refluxed for $85 \mathrm{~h}$ under an argon atmosphere and then cooled down to room temperature. The reaction crude was chromatographied on reverse $\mathrm{C} 18$ silica gel $\left(50 \% \mathrm{AcONH}_{4}(20 \mathrm{mM})\right.$ in acetonitrile). After the addition of acetic acid a solid appeared. This compound was filtered under reduced pressure to afford 2. Yield: dark purple solid (68.7 mg, $0.15 \mathrm{mmol} ; 43 \%)$.

Mp $170 \mathrm{e} 174{ }^{\circ} \mathrm{C} . \mathrm{IR}(\mathrm{KBr}): \mathrm{cm}^{-1} 2211(\mathrm{C}$ ^N), 1673 (C]O), 1531 (C]C). ${ }^{1} \mathrm{H}$ NMR $\left(300 \mathrm{MHz}, \mathrm{CDCl}_{3}\right)$ : d (ppm) $8.21(\mathrm{~s}, 1 \mathrm{H}), 7.68(\mathrm{~s}, 1 \mathrm{H})$, $6.84(\mathrm{~s}, 1 \mathrm{H}), 4.69(\mathrm{~s}, 2 \mathrm{H}), 2.14(\mathrm{~s}, 3 \mathrm{H}), 2.07(\mathrm{~s}, 3 \mathrm{H}), 0.92(\mathrm{~s}, 9 \mathrm{H}), 0.09$ (s, 6H). ${ }^{13} \mathrm{C}$ NMR (75 MHz, $\left.\mathrm{CDCl}_{3}\right)$ : d (ppm) 169.1, 149.1, 146.5, 145.5, 139.8, 136.6, 130.9, 125.6, 124.5, 116.9, 103.1, 91.5, 59.5, 25.9, 18.3, 14.0, 13.1, -5.3. HRMS $\left(\mathrm{ESI}^{\mathrm{p}}\right): \mathrm{m} / \mathrm{z}$ calcd for $\left[\mathrm{C}_{21} \mathrm{H}_{28} \mathrm{NO}_{3} \mathrm{~S}_{3} \mathrm{Si}\right]^{\mathrm{p}}$ : 466.0995, found: 466.1040 [M p H$^{\mathrm{p}}$. HRMS $\left(\mathrm{ESI}^{\mathrm{b}}\right)$ : $\mathrm{m} / \mathrm{z}$ calcd for

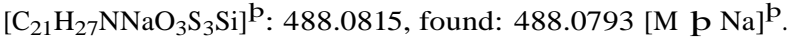

\subsubsection{3-(4-((tert-Butyldimethylsilyloxy)methyl)-5-(4-}

(diphenylamino)phenyl)thiophen-2-yl)-2-cyanoacrylic acid (3)

To a solution of aldehyde $14(139.2 \mathrm{mg} ; 0.29 \mathrm{mmol})$ and 2cyanoacetic acid (45.4 mg; $0.53 \mathrm{mmol}$ ) in chloroform $(26 \mathrm{~mL}$ ) was added piperidine $(200.6 \mathrm{~mL} ; 1.90 \mathrm{mmol})$. The mixture was refluxed for 5 days under an argon atmosphere and then cooled down to room temperature. The reaction crude was chromatographied on reverse $\mathrm{C} 18$ silica gel $\left(50 \% \mathrm{AcONH}_{4}(20 \mathrm{mM})\right.$ in acetonitrile). After the addition of acetic acid a solid appeared. This compound was filtered under reduced pressure to afford 3. Yield: pinkish solid (113.1 mg, $0.20 \mathrm{mmol} ; 70 \%$ ).

Mp 196e200 ${ }^{\circ} \mathrm{C} . \mathrm{IR}(\mathrm{KBr}): \mathrm{cm}^{-1} 2223(\mathrm{C}$ N N), 1679 (C】O), 1566 (C] C). ${ }^{1} \mathrm{H}$ NMR $\left(400 \mathrm{MHz}\right.$, acetone-d $\left.\mathrm{d}_{6}\right): \mathrm{d}(\mathrm{ppm}) 8.42(\mathrm{~s}, 1 \mathrm{H}), 8.05(\mathrm{~s}$, $1 \mathrm{H}), 7.58 \mathrm{e} 7.53(\mathrm{~m}, 2 \mathrm{H}), 7.39 \mathrm{e} 7.33(\mathrm{~m}, 4 \mathrm{H}), 7.18 \mathrm{e} 7.11(\mathrm{~m}, 6 \mathrm{H})$ $7.11 \mathrm{e} 7.06(\mathrm{~m}, 2 \mathrm{H}), 4.83$ (s, 2H), 0.91 (s, 9H), 0.11 (s, 6H). ${ }^{13} \mathrm{C}$ NMR $\left(100 \mathrm{MHz}\right.$, acetone- $\left.\mathrm{d}_{6}\right): \mathrm{d}(\mathrm{ppm}) 167.8,151.5,150.9,148.9,148.3$, 143.4, 140.7, 134.9, 131.8, 131.5, 127.4, 127.2, 126.0, 123.6, 117.8, 100.1, 60.9, 27.3, 19.8, -4.1. HRMS $\left(\mathrm{ESI}^{-}\right): \mathrm{m} / \mathrm{z}$ calcd for $\left[\mathrm{C}_{33} \mathrm{H}_{33} \mathrm{~N}_{2} \mathrm{O}_{3} \mathrm{SSi}\right]^{-}$: 565.1987, found: $565.2014[\mathrm{M}-\mathrm{H}]^{-}$.

\subsubsection{3-((tert-Butyldiphenylsilyloxy)methyl)thiophene-2- carbaldehyde (18)}

A solution of tert-butyldiphenyl(thiophen-3-ylmethoxy)silane 17 (2.2 g, $6.2 \mathrm{mmol})$ in anhydrous diethyl ether $(10 \mathrm{~mL})$ was prepared, purged with argon and cooled to $-10{ }^{\circ} \mathrm{C}$. To this solution, tBuLi (1.7 $\mathrm{M}$ in pentane) $(4 \mathrm{~mL}, 6.2 \mathrm{mmol})$ was added dropwise for a period of $20 \mathrm{~min}$ and the resulting mixture was stirred at $-10^{\circ} \mathrm{C}$ for $1 \mathrm{~h}$. Then, DMF $(0.75 \mathrm{~mL}, 9.6 \mathrm{mmol})$ was added dropwise and the 
mixture was warmed to $0{ }^{\circ} \mathrm{C}$ and stirred at this temperature overnight (TLC monitoring using 20\% hexanes in dichloromethane). Saturated $\mathrm{NH}_{4} \mathrm{Cl}$ solution was added to quench the reaction and the solvent was evaporated under reduced pressure. The organic layer was extracted with diethyl ether $(10 \times 3 \mathrm{~mL})$ and dried over anhydrous $\mathrm{MgSO}_{4}$. After removal of the solvent, the aldehyde 18 was purified by silica gel column chromatography $(20 \%$ hexanes in dichloromethane). Yield: yellow oil (454.9 mg, $1.20 \mathrm{mmol} ; 20 \%)$.

IR (neat): $\mathrm{cm}^{-1} 1664$ (C]O), 1588 (C]C). ${ }^{1} \mathrm{H}$ NMR (400 MHz, $\left.\mathrm{CD}_{2} \mathrm{Cl}_{2}\right): \mathrm{d}(\mathrm{ppm}) 9.95(\mathrm{~d}, \mathrm{~J} 1 / 40.9 \mathrm{~Hz}, 1 \mathrm{H}), 7.68 \mathrm{e} 7.66(\mathrm{~m}, 5 \mathrm{H})$, $7.48 \mathrm{e} 7.37(\mathrm{~m}, 6 \mathrm{H}), 7.25(\mathrm{~d}, \mathrm{~J} 1 / 45.0 \mathrm{~Hz}, 1 \mathrm{H}), 5.06(\mathrm{~s}, 2 \mathrm{H}), 1.08$ (s, 9H). ${ }^{13} \mathrm{C}$ NMR (100 MHz, $\mathrm{CD}_{2} \mathrm{Cl}_{2}$ ): d (ppm) 182.9, 150.9, 138.1, 136.1, 134.5, $133.5,130.5,130.0,128.5,61.4,27.2,19.7$. HRMS $\left(\operatorname{ESI}^{\mathrm{b}}\right): \mathrm{m} / \mathrm{z}$ calcd for $\left[\mathrm{C}_{22} \mathrm{H}_{25} \mathrm{O}_{2} \mathrm{SSi}\right]^{\mathrm{p}}$ : 381.1339 , found: 381.1313 [M p H$^{\mathrm{p}}$; calcd for

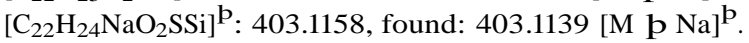

\subsubsection{4-((tert-Butyldiphenylsilyloxy)methyl)thiophene-2-}

carbaldehyde (19)

A solution of tert-butyldiphenyl(thiophen-3-ylmethoxy)silane 17 (1.6 g, $4.5 \mathrm{mmol})$ in anhydrous THF $(39 \mathrm{~mL})$ was prepared, purged with argon and cooled to $-10{ }^{\circ} \mathrm{C}$. To this solution, n-BuLi (1.6 $\mathrm{M}$ in hexanes) $(2.8 \mathrm{~mL}, 4.5 \mathrm{mmol})$ was added dropwise and the resulting mixture was stirred at $-10{ }^{\circ} \mathrm{C}$ for $1 \mathrm{~h}$ and $30 \mathrm{~min}$. Then, DMF $(0.54 \mathrm{~mL}, 6.9 \mathrm{mmol})$ was added dropwise and the mixture was warmed to $0{ }^{\circ} \mathrm{C}$ and stirred at this temperature overnight (TLC monitoring using $20 \%$ ethyl acetate in hexanes). Saturated $\mathrm{NH}_{4} \mathrm{Cl}$ solution was added to quench the reaction and the solvent was evaporated under reduced pressure. The organic layer was extracted with diethyl ether $(15 \times 2 \mathrm{~mL})$ and dried over anhydrous $\mathrm{MgSO}_{4}$. After removal of the solvent, the aldehyde 19 was purified by silica gel column chromatography $(20 \%$ ethyl acetate in hexanes). Yield: white solid (465.3 mg, $1.22 \mathrm{mmol} ; 21 \%)$.

Mp $76 \mathrm{e} 78{ }^{\circ} \mathrm{C}$. IR (KBr): $\mathrm{cm}^{-1} 1666$ (C] O), 1466 (C]C). ${ }^{1} \mathrm{H}$ NMR (400 MHz, $\left.\mathrm{CD}_{2} \mathrm{Cl}_{2}\right)$ : d (ppm) $9.86(\mathrm{~d}, \mathrm{~J} 1 / 41.3 \mathrm{~Hz}, 1 \mathrm{H}), 7.69 \mathrm{e} 7.65(\mathrm{~m}$, $5 \mathrm{H}), 7.59 \mathrm{e} 7.58(\mathrm{~m}, 1 \mathrm{H}), 7.47 \mathrm{e} 7.37(\mathrm{~m}, 6 \mathrm{H}), 4.77(\mathrm{~d}, \mathrm{~J} 1 / 40.6 \mathrm{~Hz}, 2 \mathrm{H})$, 1.08 (s, 9H). ${ }^{13} \mathrm{C}$ NMR $\left(100 \mathrm{MHz}, \mathrm{CD}_{2} \mathrm{Cl}_{2}\right)$ : d (ppm) 183.5, 144.7, 144.5, 136.1, 135.8, 133.7, 130.8, 130.4, 128.4, 62.2, 27.1, 19.7. HRMS $\left(\mathrm{ESI}^{\mathrm{b}}\right)$ : $\mathrm{m} / \mathrm{z}$ calcd for $\left[\mathrm{C}_{22} \mathrm{H}_{25} \mathrm{O}_{2} \mathrm{SSi}^{\mathrm{p}}{ }^{\mathrm{s}}: 381.1339\right.$, found: 381.1320 [M $\mathrm{p} \mathrm{H}^{\mathrm{p}}$; calcd for $\left[\mathrm{C}_{22} \mathrm{H}_{24} \mathrm{NaO}_{2} \mathrm{SSi}\right]^{\mathrm{p}}$ : 403.1158 , found: $403.1144[\mathrm{M} \mathrm{p} \mathrm{Na}]^{\mathrm{p}}$.

\subsubsection{4-((tert-Butyldiphenylsilyloxy)methyl)-5-((2,6-diphenyl-}

4H-pyran-4-ylidene)methyl)thiophene-2-carbaldehyde (21)

A solution of $5(22.6 \mathrm{mg}, 0.51 \mathrm{mmol})$ in anhydrous THF $(5 \mathrm{~mL})$ was prepared, purged with argon and cooled to $-78{ }^{\circ} \mathrm{C}$. To this solution, $\mathrm{n}$-BuLi (1.6 M in hexanes) $(0.32 \mathrm{~mL}, 0.51 \mathrm{mmol})$ was added dropwise and the resulting mixture was stirred for $20 \mathrm{~min}$. Then $3-$ ((tert-butyldiphenylsilyloxy)methyl)thiophene-2-carbaldehyde 18 (151.1 $\mathrm{mg} ; 0.40 \mathrm{mmol})$ in anhydrous THF $(5 \mathrm{~mL})$ was added dropwise and the mixture was warmed to room temperature for $21 \mathrm{~h}$ (TLC monitoring using 10\% dichloromethane in hexanes). Saturated $\mathrm{NH}_{4} \mathrm{Cl}$ solution was added to quench the reaction and the solvent was evaporated under reduced pressure. The organic layer was extracted with hexanes $(25 \times 2 \mathrm{~mL})$ and dried over anhydrous $\mathrm{MgSO}_{4}$. After the removal of the solvent, the residue was dissolved in hexanes $/ \mathrm{CH}_{2} \mathrm{Cl}_{2}(9 / 1)$ and filtered over silica gel to give the compound 20 as an intermediate. A solution of 20 in THF $(10 \mathrm{~mL})$ was prepared, purged with argon and cooled to $-78{ }^{\circ} \mathrm{C}$. To this solution, $\mathrm{n}$-BuLi (1.6 $\mathrm{M}$ in hexanes) $(0.36 \mathrm{~mL}, 0.58 \mathrm{mmol})$ was added dropwise and the resulting mixture was stirred for $1 \mathrm{~h}$ and $30 \mathrm{~min}$. DMF $(0.08 \mathrm{~mL}, 1.03 \mathrm{mmol})$ was added dropwise and the mixture stirred for $2 \mathrm{~h}$. Saturated $\mathrm{NH}_{4} \mathrm{Cl}$ solution was added to quench the reaction and the solvent was evaporated under reduced pressure. The organic layer was extracted with hexanes $(15 \times 2 \mathrm{~mL})$ and dried over anhydrous $\mathrm{MgSO}_{4}$. After the removal of the solvent, the aldehyde 21 was purified by silica gel column chromatography (20\% ethyl acetate in hexanes). Yield: red oil (136.4 mg, $0.22 \mathrm{mmol} ; 55 \%)$.

IR (neat): $\mathrm{cm}^{-1} 1643$ (C]O), 1518 (C]C). ${ }^{1} \mathrm{H}$ NMR (400 MHz, $\left.\mathrm{CD}_{2} \mathrm{Cl}_{2}\right)$ : d (ppm) $9.77(\mathrm{~s}, 1 \mathrm{H}), 7.92 \mathrm{e} 7.89(\mathrm{~m}, 2 \mathrm{H}), 7.80 \mathrm{e} 7.78(\mathrm{~m}, 2 \mathrm{H})$, $7.75 \mathrm{e} 7.67(\mathrm{~m}, 4 \mathrm{H}), 7.64(\mathrm{~s}, 1 \mathrm{H}), 7.55 \mathrm{e} 7.38(\mathrm{~m}, 12 \mathrm{H}), 7.27(\mathrm{~d}, \mathrm{~J} 1 / 42.0$ $\mathrm{Hz}, 1 \mathrm{H}), 6.47$ (d, J 1 $1 / 42.0 \mathrm{~Hz}, 1 \mathrm{H}), 6.00(\mathrm{~s}, 1 \mathrm{H}), 4.81$ (s, 2H), 1.09 (s, 9H). ${ }^{13} \mathrm{C}$ NMR $\left(100 \mathrm{MHz}, \mathrm{CD}_{2} \mathrm{Cl}_{2}\right): \mathrm{d}(\mathrm{ppm}) 182.4,155.8,153.0,147.1,139.1$, $138.5,137.8,136.2,133.8,133.2,133.1,133.0,130.7,130.4,130.2$, 129.4, 129.3, 128.4, 125.9, 125.2, 109.5, 105.4, 103.3, 60.9, 27.2, 19.7. HRMS $\left(\mathrm{ESI}^{\mathrm{b}}\right): \mathrm{m} / \mathrm{z}$ calcd for $\left[\mathrm{C}_{40} \mathrm{H}_{37} \mathrm{O}_{3} \mathrm{SSi}\right]^{\mathrm{p}}$ : 625.2227, found: $625.2235[\mathrm{M} \mathrm{p} \mathrm{H}]^{\mathrm{p}}$.

2.2.11. 3-((tert-Butyldiphenylsilyloxy)methyl)-5-((2,6-diphenyl-4Hpyran-4-ylidene)methyl)thiophene-2-carbaldehyde (23)

A solution of 2,6-diphenyl(4H-pyran-4ylidene)diphenylphosphine oxide $5(222.6 \mathrm{mg}, 0.51 \mathrm{mmol})$ in anhydrous THF $(5 \mathrm{~mL})$ was prepared, purged with argon and cooled to $-78^{\circ} \mathrm{C}$. To the solution, $\mathrm{n}$-BuLi (1.6 $\mathrm{M}$ in hexanes) $(0.32 \mathrm{~mL}, 0.51 \mathrm{mmol})$ was added dropwise and the resulting mixture was stirred for $20 \mathrm{~min}$. Then 4((tert-butyldiphenylsilyloxy)methyl)thiophene-2-carbaldehyde 19 (150.0 $\mathrm{mg} ; 0.39 \mathrm{mmol})$ in anhydrous THF $(5 \mathrm{~mL})$ was added dropwise and the mixture was warmed to room temperature for $21 \mathrm{~h}$ (TLC monitoring using $20 \%$ ethyl acetate in hexanes). Saturated $\mathrm{NH}_{4} \mathrm{Cl}$ solution was added to quench the reaction and the solvent was evaporated under reduced pressure. The organic layer was extracted with EtOAc and dried over anhydrous $\mathrm{MgSO}_{4}$. After the removal of the solvent, the residue was dissolved in EtOAc/hexanes (2:8) and filtered over silica gel to give the crude tert-butyl $((5-)(2,6-$ diphenyl-4H-pyran-4-ylidene)methyl)thiophen-3-yl)methoxy) diphenylsilane 22 as an intermediate. A solution of 22 in THF $(10 \mathrm{~mL})$ was prepared, purged with argon and cooled to $-78^{\circ} \mathrm{C}$. To this solution, $\mathrm{n}$-BuLi $(1.6 \mathrm{M}$ in hexanes) $(0.42 \mathrm{~mL}, 0.68 \mathrm{mmol})$ was added dropwise and the resulting mixture was stirred for $2 \mathrm{~h}$. DMF (0.09 $\mathrm{mL}, 1.2 \mathrm{mmol})$ was added dropwise and the mixture stirred for $2 \mathrm{~h}$. Saturated $\mathrm{NH}_{4} \mathrm{Cl}$ solution was added to quench the reaction and the solvent was evaporated under reduced pressure. The organic layer was extracted with EtOAc $(15 \times 3 \mathrm{~mL})$ and dried over anhydrous $\mathrm{MgSO}_{4}$. After the removal of the solvent, the aldehyde 23 was purified by silica gel column chromatography (20\% ethyl acetate in hexanes). Yield: dark red oil (138.9 mg, $0.22 \mathrm{mmol} ; 56 \%)$.

IR (neat): $\mathrm{cm}^{-1} 1643$ (C]O), 1579 (C]C). ${ }^{1} \mathrm{H}$ NMR (400 MHz, $\left.\mathrm{CD}_{2} \mathrm{Cl}_{2}\right)$ : d (ppm) $9.86(\mathrm{~s}, 1 \mathrm{H}), 7.90 \mathrm{e} 7.88(\mathrm{~m}, 2 \mathrm{H}), 7.82 \mathrm{e} 7.80(\mathrm{~m}, 2 \mathrm{H})$, $7.73 \mathrm{e} 7.70(\mathrm{~m}, 4 \mathrm{H}), 7.50 \mathrm{e} 7.41(\mathrm{~m}, 12 \mathrm{H}), 7.22(\mathrm{~d}, \mathrm{~J} 1 / 41.9 \mathrm{~Hz}, 1 \mathrm{H}), 7.05$ $(\mathrm{s}, 1 \mathrm{H}), 6.55(\mathrm{~d}, \mathrm{~J} 1 / 41.9 \mathrm{~Hz}, 1 \mathrm{H}), 6.14(\mathrm{~s}, 1 \mathrm{H}), 5.02(\mathrm{~s}, 2 \mathrm{H}), 1.11(\mathrm{~s}, 9 \mathrm{H})$. ${ }^{13} \mathrm{C}$ NMR (100 MHz, $\mathrm{CD}_{2} \mathrm{Cl}_{2}$ ): d (ppm) 181.4, 155.6, 153.1, 151.5, 151.3, $136.1,133.7,133.5,133.3,133.2,133.1,130.7,130.5,130.2,129.4$, 129.3, 128.4, 127.8, 125.9, 125.3, 109.1, 107.6, 103.2, 61.2, 27.2, 19.7. HRMS $\left(\mathrm{ESI}^{\mathrm{b}}\right): \mathrm{m} / \mathrm{z}$ calcd for $\left[\mathrm{C}_{40} \mathrm{H}_{37} \mathrm{O}_{3} \mathrm{SSi}\right]^{\mathrm{p}}$ : 625.2227, found: $625.2244[\mathrm{M} \mathrm{p} \mathrm{H}]^{\mathrm{p}}$.

2.2.12. 3-(4-((tert-Butyldiphenylsilyloxy)methyl)-5-((2,6-diphenyl4H-pyran-4-ylidene)methyl)thiophen-2-yl)-2-cyanoacrylic acid (15)

To a solution of aldehyde $21(97.9 \mathrm{mg}, 0.157 \mathrm{mmol})$ and 2cyanoacetic acid $(20.8 \mathrm{mg}, 0.24 \mathrm{mmol})$ in chloroform $(16 \mathrm{~mL})$ was added piperidine $(109.9 \mathrm{~mL}, 1.04 \mathrm{mmol})$. The mixture was refluxed for $72 \mathrm{~h}$ under an argon atmosphere and then cooled down to room temperature. The reaction crude was chromatographied on reverse C18 silica gel (started $50 \% \mathrm{AcONH}_{4}(20 \mathrm{Mm})$ in acetonitrile and finished $30 \%$ ). After the addition of acetic acid a solid appeared. This compound was filtered under reduced pressure to afford 15. Yield: dark purple solid (83.4 $\mathrm{mg}, 0.12 \mathrm{mmol} ; 77 \%)$.

Mp $208 \mathrm{e}^{2} 11^{\circ} \mathrm{C} . \mathrm{IR}(\mathrm{KBr}): \mathrm{cm}^{-1} 2207(\mathrm{C} \wedge \mathrm{N}), 1652$ (C]O), 1539 (C]C). ${ }^{1} \mathrm{H}$ NMR (300 MHz, THF-d ${ }_{8}$ ): d (ppm) 8.29 (s, 1H), 8.01e7.98 $(\mathrm{m}, 2 \mathrm{H}), 7.88 \mathrm{e} 7.85(\mathrm{~m}, 2 \mathrm{H}), 7.79(\mathrm{~s}, 1 \mathrm{H}), 7.76 \mathrm{e} 7.70(\mathrm{~m}, 4 \mathrm{H})$, 
$7.59 \mathrm{e} 7.32(\mathrm{~m}, 13 \mathrm{H}), 6.76(\mathrm{~d}, \mathrm{~J} 1 / 41.6 \mathrm{~Hz}, 1 \mathrm{H}), 6.12(\mathrm{~s}, 1 \mathrm{H}), 4.87$ (s, 2H), 1.09 (s, 9H). ${ }^{13} \mathrm{C}$ NMR (100 MHz, THF-d $\left.\mathrm{d}_{8}\right): \mathrm{d}$ (ppm) 164.9, 156.6, 153.8, 147.8, 146.1 139.8, 139.8, 136.6, 134.3, 134.0, 133.7, 133.5, 131.9, $130.9,130.6,130.0,129.7,128.8,126.2,125.7,117.9,110.2,106.2$, 104.0, 96.6, 61.3, 27.4, 20.1. HRMS $\left(\mathrm{ESI}^{\mathrm{b}}\right): \mathrm{m} / \mathrm{z}$ calcd for

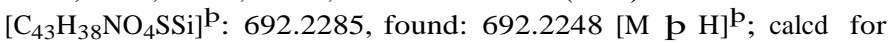
$\left[\mathrm{C}_{43} \mathrm{H}_{37} \mathrm{NNaO}_{4} \mathrm{SSi}^{\mathrm{p}} \text { : } 714.2105 \text {, found: } 714.2066 \text { [M p Na }\right]^{\mathrm{p}}$.

2.2.13. 3-(3-((tert-Butyldiphenylsilyloxy)methyl)-5-((2,6-diphenyl4H-pyran-4-ylidene)methyl)thiophen-2-yl)-2-cyanoacrylic acid (16)

To a solution of aldehyde $23(120.4 \mathrm{mg}, 0.192 \mathrm{mmol})$ and 2cyanoacetic acid $(25.6 \mathrm{mg}, 0.30 \mathrm{mmol})$ in chloroform $(18 \mathrm{~mL})$ was added piperidine $(134.6 \mathrm{~mL}, 1.28 \mathrm{mmol})$. The mixture was refluxed for $20 \mathrm{~h}$ under an argon atmosphere, then cooled down to room temperature. The reaction crude was chromatographed on reverse C18 silica gel (started 50\% $\mathrm{AcONH}_{4}(20 \mathrm{mM})$ in acetonitrile and finished 33\%). After the addition of acetic acid a solid appeared. This compound was filtered under reduced pressure to afford 16. Yield: dark purple solid $(86.0 \mathrm{mg}, 0.12 \mathrm{mmol} ; 65 \%)$.

Mp 219e226 ${ }^{\circ} \mathrm{C} . \mathrm{IR}(\mathrm{KBr}): \mathrm{cm}^{-1} 2209(\mathrm{C}$ 人 N), 1651 (C]O), 1541 (C] C). ${ }^{1} \mathrm{H}$ NMR $\left(400 \mathrm{MHz}, \mathrm{THF}-\mathrm{d}_{8}\right)$ : d (ppm) $8.51(\mathrm{~s}, 1 \mathrm{H}), 7.99 \mathrm{e} 7.88$ (m, 4H), 7.74e7.72 (m, 4H), 7.49e7.34 (m, 14H), 6.99 (s, 1H), $6.81(\mathrm{br}$ $\mathrm{s}, 1 \mathrm{H}), 4.92$ (s, 2H), 1.08 (s, 9H). ${ }^{13} \mathrm{C}$ NMR (100 MHz, THF-d 8 ): d (ppm) $164.9,156.4,154.0,152.5,151.7,143.7,136.6,134.3,134.0,133.7$, $133.5,131.9,131.2,130.9,130.7,130.0,129.8,128.8,128.1,126.2$, $125.8,118.1,109.8,108.4,103.9,95.8,61.3,27.4,20.0$. HRMS $\left(\mathrm{ESI}^{\mathrm{p}}\right)$ : $\mathrm{m} / \mathrm{z}$ calcd for $\left[\mathrm{C}_{43} \mathrm{H}_{38} \mathrm{NO}_{4} \mathrm{SSi}\right]^{\mathrm{p}}$ : 692.2285 , found: 692.2313 .

\subsection{Device preparation and characterization}

The working and counter electrodes consisted of $\mathrm{TiO}_{2}$ and thermalized platinum films, respectively, and were deposited onto F-doped tin oxide (FTO, Pilkington Glass Inc., with $15 \mathrm{U} \mathrm{sq}^{-1}$ sheet resistance) conducting glass substrates. Efficient DSC devices were made using $9 \mathrm{~mm}$ thick films consisting of $20 \mathrm{~nm} \mathrm{TiO} 2$ nanoparticles (Dyesol ${ }^{\odot}$ paste) and a scattering layer of $4 \mathrm{~mm}$ of $400 \mathrm{~nm} \mathrm{TiO}_{2}$ particles (Dyesol ${ }^{\odot}$ paste). Prior to the deposition of the $\mathrm{TiO}_{2}$ paste, the conducting glass substrates were immersed in a solution of $\mathrm{TiCl}_{4}(40 \mathrm{mM})$ for $30 \mathrm{~min}$ and then dried. The $\mathrm{TiO}_{2}$ nanoparticle paste was deposited onto a conducting glass substrate using the screen printing technique. The $\mathrm{TiO}_{2}$ electrodes were gradually heated under an air flow at $325{ }^{\circ} \mathrm{C}$ for $5 \mathrm{~min}, 375{ }^{\circ} \mathrm{C}$ for $5 \mathrm{~min}$, $450{ }^{\circ} \mathrm{C}$ for $15 \mathrm{~min}$ and $500{ }^{\circ} \mathrm{C}$ for $15 \mathrm{~min}$. The heated $\mathrm{TiO}_{2}$ electrodes were immersed again in a solution of $\mathrm{TiCl}_{4}(40 \mathrm{mM})$ at $70{ }^{\circ} \mathrm{C}$ for $30 \mathrm{~min}$ and then washed with ethanol. The electrodes were heated again at $500{ }^{\circ} \mathrm{C}$ for $30 \mathrm{~min}$ and cooled before dye adsorption. The active area for devices was $0.16 \mathrm{~cm}^{2}$. The counter electrode was made by spreading a $5 \mathrm{mM}$ solution of $\mathrm{H}_{2} \mathrm{PtCl}_{6}$ in isopropyl alcohol onto a conducting glass substrate containing a small hole to allow the introduction of the liquid electrolyte using vacuum, followed by heating at $390{ }^{\circ} \mathrm{C}$ for $15 \mathrm{~min}$. All films were sensitized in $0.3 \mathrm{mM}$ dye solutions in dichloromethane for $2 \mathrm{~h}$ at room temperature (optimized dye loading conditions). The sensitized electrodes were washed with dichloromethane and dried under air. Finally, the working and counter electrodes were sandwiched together using a thin thermoplastic (Surlyn) frame that melts at $100{ }^{\circ} \mathrm{C}$. Electrolyte LP1 was used: consisted of $0.5 \mathrm{M}$ 1-butyl-3-methylimidazolium iodide (BMII), 0.1 M lithium iodide, $0.05 \mathrm{M}$ iodine and $0.5 \mathrm{M}$ tertbutylpyridine in acetonitrile.

The J/V curves of the cells were measured using a Sun 2000 solar simulator equipped with a $150 \mathrm{~W}$ xenon lamp. The illumination

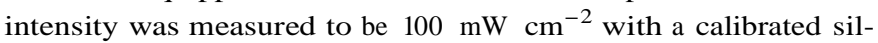
icon photodiode. The appropriate filters were utilized to faithfully simulate the AM $1.5 \mathrm{G}$ spectrum. The applied potential and cell current were measured using a Keithley 2400 digital source meter. The IPCE (incident photon to current conversion efficiency) was measured using a home-made set up consisting of a $150 \mathrm{~W}$ Oriel xenon lamp, a motorized monochromator and a Keithley 2400 digital source meter.

Transient photovoltage (TPV) and charge extraction (CE) measurements were carried out alike reported before [36]. In CE measurements, white light from a series of LEDs was used as the light source. When the LEDs are turned off, the cell is immediately shortcircuited and the charge is extracted allowing the electron density in the cells to be calculated. By changing the intensity of the LEDs, the electron density can be estimated as a function of cell voltage. In TPV measurements, in addition to the white light applied by the LEDS, a diode pulse $(660 \mathrm{~nm}, 10 \mathrm{~mW})$ is applied to the sample inducing a change of $2 \mathrm{e} 3 \mathrm{mV}$ within the cell. The resulting photovoltage decay transients are collected and the $t$ values are determined by fitting the data to the equation $\exp (-t / t)$.

\subsection{Computational details}

Density Functional Theory (DFT) calculations were performed using Gaussian 09 [37] with the ultrafine integration grid. Solvent effects were estimated using a Conductor-like Polarizable Continuum Model (CPCM) [38,39]. Equilibrium geometries were optimized using the M06-2x hybrid meta-GGA exchange correlation functional [40] and the medium size $6 \mathbf{e} 31 \mathrm{G}^{*}$ base [41]. Ground state geometries were characterized as minima by frequency calculations. Excitation energies were calculated by time-dependent single point calculations using the M06-2x/6e 311 p G (2d,p) model chemistry. Absorption spectra were estimated through the calculation of vertical excitations at the ground state geometry and emission spectra, through the calculation of vertical excitations at the excited state geometry. Due to the large computational cost required to calculate excited state vibrational energies, $\mathrm{E}_{0-0}$ were approached to adiabatic excitation energies $\left(\mathrm{E}_{\mathrm{Adia}}\right)$. Ground state oxidation potentials $\left(\mathrm{E}_{\mathrm{ox}}\right)$ were calculated using the M06-2x/ 6 e 311 p G (2d,p) energies and calculating the thermal corrections to Gibbs free energy at the M06-2x/6e $31 G^{*}$ level. Excited state oxidation potentials were estimated subtracting $\mathrm{E}_{0-0}$ from $\mathrm{E}_{\mathrm{OX}}$.

Molecular Orbital contour plots were obtained using the Avogadro software [42] at 0.04 isosurface value.

\section{Results and discussion}

\subsection{Synthesis}

The target compounds 1,2 , and 3 were prepared via condensation of the corresponding aldehyde derivative $(7,10,14)$ and cyanoacetic acid in the presence of piperidine (Scheme 1).

Aldehydes 7 and 10 were synthesized by a WittigeHorner or Wittig reaction of the diphenylphosphine oxide 5 [43] or the phosphonium salt 8 [44] with aldehyde 4 [45], followed by lithiation of the resulting intermediates 6 and 9 and reaction with anhydrous DMF (Scheme 2). A different approach was adopted for the aldehyde 14 (Scheme 3) which was prepared through a Stille reaction between the stannane 12 [46] and the compound 11 [47], followed by lithiation and formylation with DMF.

\subsection{Optical properties}

The absorption spectra of the synthesized dyes were studied in $10^{-5} \mathrm{M} \mathrm{CH}_{2} \mathrm{Cl}_{2}$ solution (Fig. 3) and the relevant optical data are listed in Table 1 . Two absorption bands can be observed for all dyes, one between 300 and $400 \mathrm{~nm}$ assigned to a pep* transition and the main band between 400 and $700 \mathrm{~nm}$ due to the ICT among the 


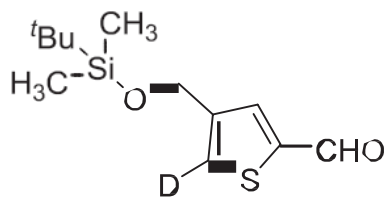

$$
\begin{aligned}
7 \mathrm{D} & =4 H-\mathrm{pyr} \\
\mathbf{1 0} \mathrm{D} & =1,3-\mathrm{DT} \\
14 \mathrm{D} & =\text { TPA }
\end{aligned}
$$

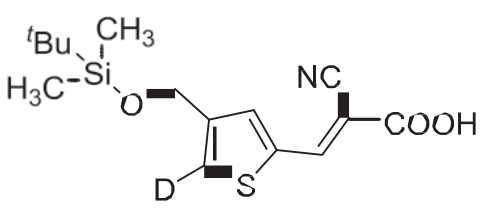

$1 \mathrm{D}=4 H$-pyr

$2 \mathrm{D}=1,3-\mathrm{DT}$

$3 \mathrm{D}=\mathrm{TPA}$<smiles>Cc1ccc(N(c2ccccc2)c2ccccc2)cc1</smiles>

TPA

Scheme 1. Synthesis of dyes 1 e3.
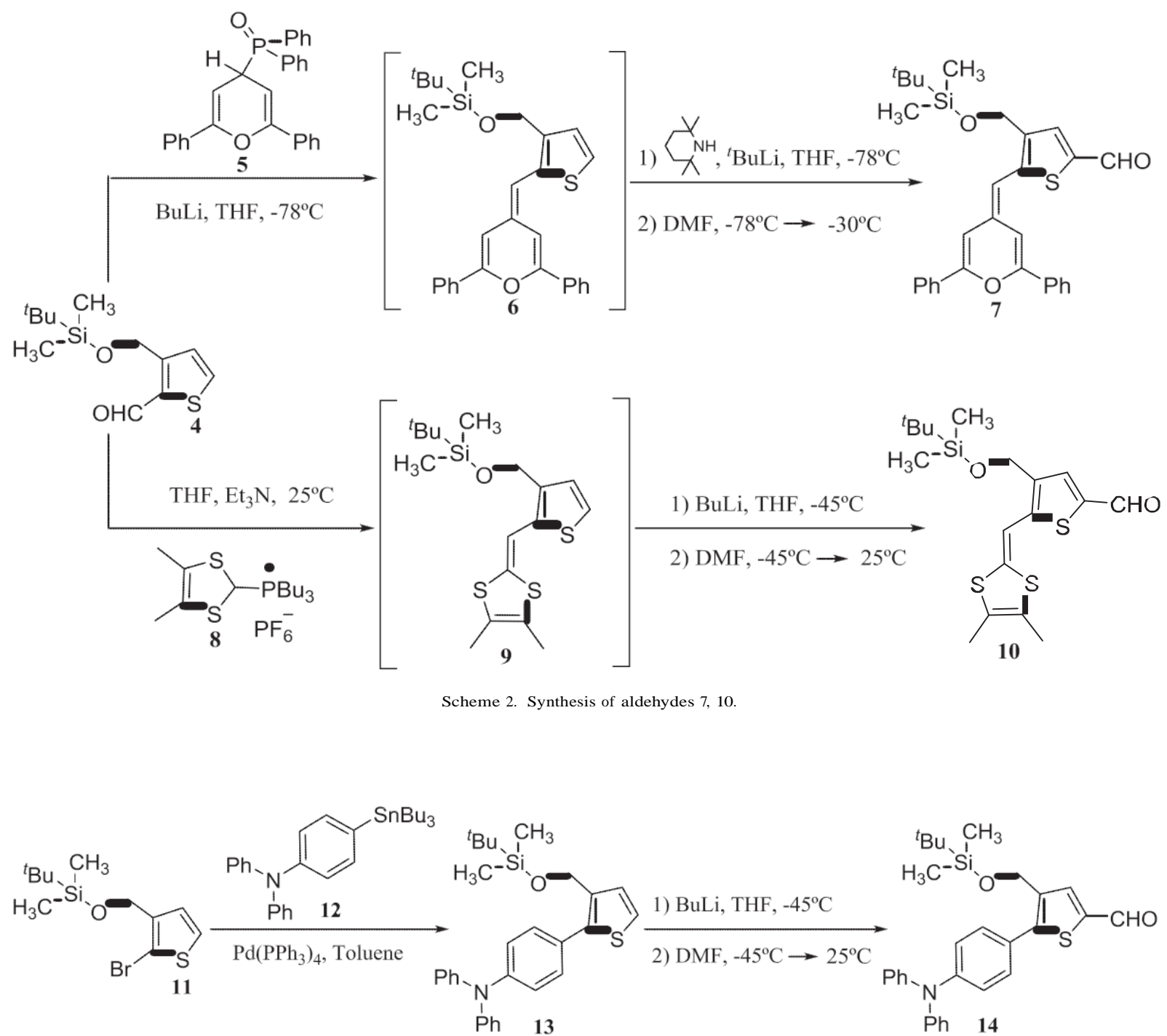

Scheme 3. Synthesis of aldehyde 14 . 


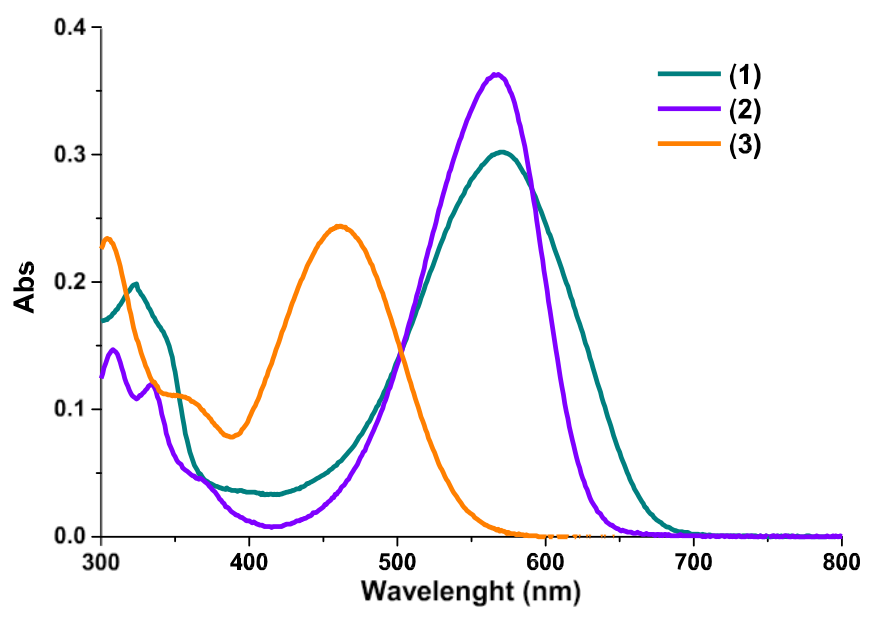

Fig. 3. Normalized UVevis absorption of compounds 1 e3.

donor and the acceptor units. The inclusion of a proaromatic donor like 4H-pyranylidene or dithiafulvene results in a red-shift of the absorption when compared to the triarylamine dye. The molar extinction coefficients of the dyes increase in the order triarylamine $<4 \mathrm{H}$-pyranylidene $<$ dithiafulvene, being for the last one $37,108 \mathrm{M}^{-1} \mathrm{~cm}^{-1}$. When the dyes are attached to $\mathrm{TiO}_{2}$ surface, they present broader bands than in solution and the maximum absorption peaks are around $30 \mathrm{~nm}$ blue-shifted. In general, the blue shifts of the absorption spectra on $\mathrm{TiO}_{2}$ are ascribed to the deprotonation of the carboxylic acid when anchored on the titanium surface and/or to the formation of H-aggregates [48].

\subsection{Electrochemical properties}

The oxidation potential $\left(E_{o x}\right)$ of each dye was determined in solution by differential pulse voltammetry (DPV) methods. $\mathrm{E}^{*}{ }_{\text {ox }}$ was estimated from $\mathrm{E}_{\mathrm{ox}}-\mathrm{E}_{0-0}$ (Table 1, see also energy diagram shown in SI Fig. S-33).

The donor unit affects significantly the oxidation potential values, with an increase on the ease of oxidation in the order $3<2<1$, pointing to the superior donor ability of the $4 \mathrm{H}-$ pyranylidene moiety. The regeneration of the oxidized dye after electron injection into the conduction band of $\mathrm{TiO}_{2}$ is guaranteed in all cases, as the $\mathrm{E}_{\mathrm{ox}}$ values are more positive than the potential of the iodide/triiodide redox couple (p0.42 vs. NHE), indicating that the oxidized dyes formed after the electron injection into the $\mathrm{TiO}_{2}$ electrode could thermodynamically accept electrons from $\mathrm{I}^{-}$ions.

The resulting values for all the dyes were almost similar and sufficiently more negative than the energy conduction band edge energy level of $\mathrm{TiO}_{2}(-0.5 \mathrm{~V}$ vs. NHE), indicating an efficient injection of electrons into the $\mathrm{TiO}_{2}$ from the excited dyes.
Table 2

Photovoltaic properties of DSSCs constructed using the dyes 1e3.

\begin{tabular}{lllll}
\hline Dye & $\mathrm{J}_{\mathrm{sc}}\left(\mathrm{mA} \mathrm{cm} \mathrm{cm}^{-2}\right)$ & $\mathrm{V}_{\mathrm{oc}}(\mathrm{V})$ & $\mathrm{ff}$ & $\mathrm{h}(\%)$ \\
\hline 1 & 11.74 & 0.644 & 74 & 5.56 \\
2 & 6.99 & 0.609 & 69 & 2.91 \\
3 & 7.26 & 0.759 & 74 & 4.09 \\
\hline
\end{tabular}

\subsection{Photovoltaic properties of DSSCs}

The device performance (with an effective area of $0.16 \mathrm{~cm}^{2}$ ) were measured under sun-simulated AM 1.5 G irradiation $\left(100 \mathrm{~mW} / \mathrm{cm}^{2}\right)$. The optimized conditions for these dyes are determined to be $0.3 \mathrm{mM}$ of dye in dichloromethane solution, $2 \mathrm{~h}$ of immersion and LP1 (0.5 M BMII/0.05 $\mathrm{M} \mathrm{I}_{2} / 0.5 \mathrm{M}$ TBP/0.1 $\mathrm{M} \mathrm{LiI}$ in acetonitrile) as electrolyte. The relevant photovoltaic parameters $\mathrm{V}_{\mathrm{oc}}, \mathrm{J}_{\mathrm{sc}}, \mathrm{ff}$, and solar-to-electrical energy conversion efficiencies (h) are collected in Table 2. Moreover, current densityevoltage (JeV) curves and incident photon-to- current conversion efficiencies (IPCE) of devices based on these dyes are represented in Fig. 4.

The IPCE tendencies of these dyes are in accordance with their UVevis absorption spectra on the $\mathrm{TiO}_{2}$ film. The onset of the IPCE spectra for dyes 1 and 2 are significantly broadened compared with the obtained for dye 3 . These results confirm the higher $J_{s c}$ value obtained for devices based on dye 1 , with a broad and roughly constant photoresponse $(\sim 60 \%)$ in the range 450 e600 $\mathrm{nm}$. Dye 3 presents a maximum IPCE value of $93 \%$ at $475 \mathrm{~nm}$ and the highest $\mathrm{V}_{\mathrm{oc}}$ value $(0.759 \mathrm{~V})$ of all the molecules studied, suggesting a decrease in the charge recombination processes for this molecule. However, its $\mathrm{J}_{\mathrm{sc}}$ is $60 \%$ lower than obtained for compound 1, probably due to the narrower IPCE observed band.

Data in Table 2 indicate that the more efficient donor system is the $4 \mathrm{H}$-pyranylidene (h $1 / 45.56 \%$ ), followed by the triarylamine system (h $1 / 44.09 \%$ ) and finally the 1,3-dithiole (h $1 / 42.91 \%$ ).

\subsection{Structural modification of the thiophene ring and physical properties}

With the aim of understanding the influence of a different bulky silyl ether group and its position in the thiophene ring, dyes 15 and 16 were synthesized by a Knoevenagel condensation of the unreported aldehydes 21 and 23 with 2-cyanoacetic acid (Scheme 4). We have chosen the pyranylidene system as donor group due to the best results obtained in the previous section. These precursors were obtained in a three-step synthetic route starting in both cases from compound 17 [49]. Lithiation conditions (base and solvent) were finely tuned in order to activate position 2 (tert- $\mathrm{BuLi}, \mathrm{Et}_{2} \mathrm{O}$ ) or position 5 (BuLi, THF) (Scheme 5). Finally, compounds 18 and 19 were obtained by reaction of the organolithium intermediates with DMF. Next, a Horner reaction of diphenylphosphine oxide 5 with 18 or 19 afforded the corresponding pyranylidene-thiophene derivatives 20

Table 1

Optical and electrochemical properties of dyes $1 \mathrm{e} 3$

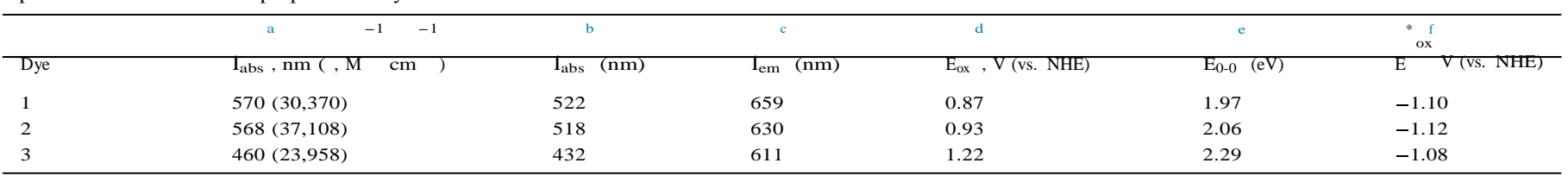

${ }^{a}$ Absorption maxima in $\mathrm{CH}_{2} \mathrm{Cl}_{2}$ solution.

b Absorption maxima on $\mathrm{TiO}_{2}$ films.

c Emission spectra were recorded in $\mathrm{CH}_{2} \mathrm{Cl}_{2}$.

${ }^{\mathrm{d}}$ First oxidation potentials were measured from three electrode electrochemical cell in $\mathrm{CH}_{2} \mathrm{Cl}_{2}$ containing $0.1 \mathrm{M} \mathrm{TBAPF}$. A glassy carbon, $\mathrm{Ag} / \mathrm{AgCl}$ ( $\mathrm{KCl} 3 \mathrm{M}$ ), and $\mathrm{Pt}$ were used as working, reference, and counter electrode respectively.

e Zerothezeroth transition energies estimated from the intersection of normalized absorption and emission spectra in $\mathrm{CH}_{2} \mathrm{Cl}_{2}$ solution.

${ }^{f}$ Excited-state oxidation potentials of the dyes obtained from $\mathrm{E}_{\mathrm{ox}}-\mathrm{E}_{\mathrm{O}-\mathrm{O}}$. 

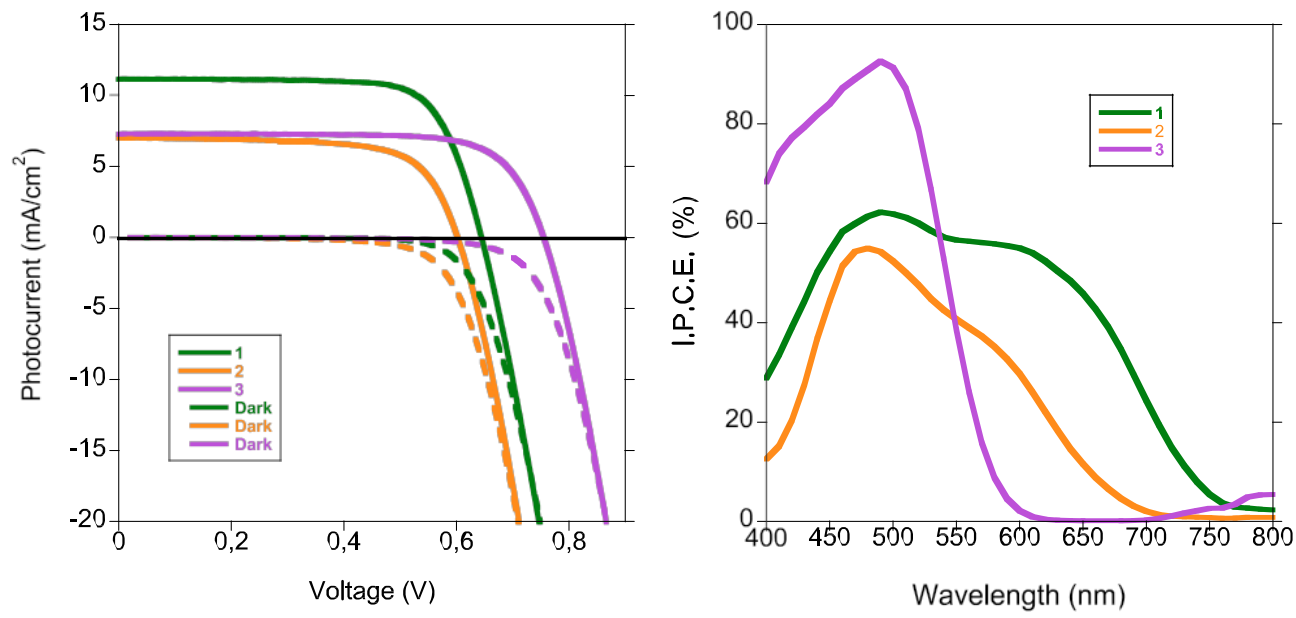

Fig. 4. JeV curves of compounds 1 e3 (left) and IPCE curves of 1 e3 (right).<smiles>[R]c1c(C=C2C=C(c3ccccc3)OC(c3ccccc3)=C2)sc(CCl)c1[R2]</smiles>

$21 \mathrm{R}_{1}=\mathrm{CH}_{2} \mathrm{OTBDPS}, \mathrm{R}_{2}=\mathrm{H}$ $23 \mathrm{R}_{1}=\mathrm{H}, \mathrm{R}_{2}=\mathrm{CH}_{2} \mathrm{OTBDPS}$

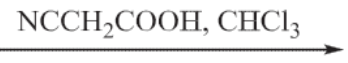

Piperidine, $65^{\circ} \mathrm{C}$<smiles></smiles>

$15 \mathrm{R}_{1}=\mathrm{CH}_{2} \mathrm{OTBDPS}, \mathrm{R}_{2}=\mathrm{H}$

$16 \mathrm{R}_{1}=\mathrm{H}, \mathrm{R}_{2}=\mathrm{CH}_{2} \mathrm{OTBDPS}$

Scheme 4. Synthesis of dyes $15,16$.

and 22, which by lithiation and reaction with DMF yielded final aldehydes 21 and 23 respectively (Scheme 6).

The substitution of a TBDMS group (1) by a tert-butyldiphenylsilyl (TBDPS (15)) does not change significantly the maximum absorption peak ( $570 \mathrm{~nm}$ for 1 and $573 \mathrm{~nm}$ for 15). By contrast, the molar extinction coefficient ( ) is enhanced on passing from TBDMS to TBDPS (30,370 $\mathrm{M}^{-1} \mathrm{~cm}^{-1}$ (1) to $33,618 \mathrm{M}^{-1} \mathrm{~cm}^{-1}$ (15)), probably due to the incorporation of two additional phenyl groups. Moreover, a bigger enhancement of the is found when the silyloxy substituent is located at the position 3 of the thiophene ring instead of the position 4 (from 33,618 (15) to $39,963 \mathrm{M}^{-1} \mathrm{~cm}^{-1}$ (16)).

Regarding the electrochemical properties, it has to be pointed that the $\mathrm{E}_{\mathrm{ox}}$ values for systems 1,15 and 16 are very similar (b0.87, p0.90, and p0.88 V respectively, measured in conditions indicated in Table 1) and hence, the influence of the bulky substituent and its position is fairly null (see SI Fig. S-34).

We have tested the photovoltaic response of dyes 15 and 16 (Fig. 5) in DSSCs and their results were compared with those of compound 1 (Table 3). The substitution of a TBDMS group (1) by the bulkier group (TBDPS) (15) improves slightly the efficiency (from $5.56 \%$ to $5.86 \%$ ), mostly due to a better value of the $\mathrm{V}_{\mathrm{oc}}$ for the last one. This result suggests that a TBDPS group retards the recombination of $\mathrm{TiO}_{2}$ conduction band electrons with the electrolyte as it has been shown from charge extraction and transient photovoltage experiments (see below) [50].

The influence of the position of the silyl ether group was also studied and we have found that the solar cell based on dye 16 (with a higher molecular extinction coefficient) shows an efficiency of $3.42 \%, 42 \%$ lower that obtained for dye 15 . The decrease in the efficiency is mainly due to a lower $\mathrm{J}_{\mathrm{sc}}$ and $\mathrm{V}_{\mathrm{oc}}$, to a lesser extent. The remarkable decrease of $\mathrm{J}_{\mathrm{sc}}$ was attributed to the lower injection efficiency, probably affected by the amount of dye absorbed to the $\mathrm{TiO}_{2}$ surface.

Desorption experiments ( $0.1 \mathrm{M} \mathrm{NaOH}$, EtOH: $\left.\mathrm{H}_{2} \mathrm{O}(1: 1)\right)$ determined that dye 16 is less adsorbed $\left(106 \mathrm{nmol} / \mathrm{cm}^{2}\right)$ than dye 15 $\left(140 \mathrm{nmol} / \mathrm{cm}^{2}\right)$ and this observation was attributed to the steric hindrance of the TBDPS group which is closer to the anchor group. Moreover, a lower amount of dye absorbed could result in higher concentration in the interface $\mathrm{TiO}_{2} /$ electrolyte, increasing the recombination processes.

Fig. 6 illustrates the charge density (charge accumulated at the device under different light bias) and the charge lifetime at a given

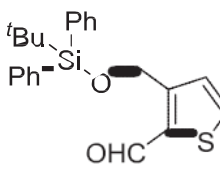

1) ${ }^{t} \mathrm{BuLi}, \mathrm{Et}_{2} \mathrm{O},-10^{\circ} \mathrm{C}$

2) DMF

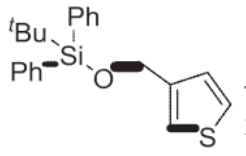

1) $\mathrm{BuLi}, \mathrm{THF},-10^{\circ} \mathrm{C}$

2) $\mathrm{DMF},-10^{\circ} \mathrm{C} \rightarrow 0^{\circ} \mathrm{C}$

17

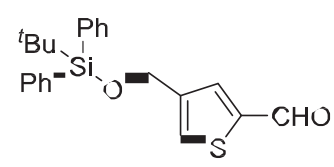

19 


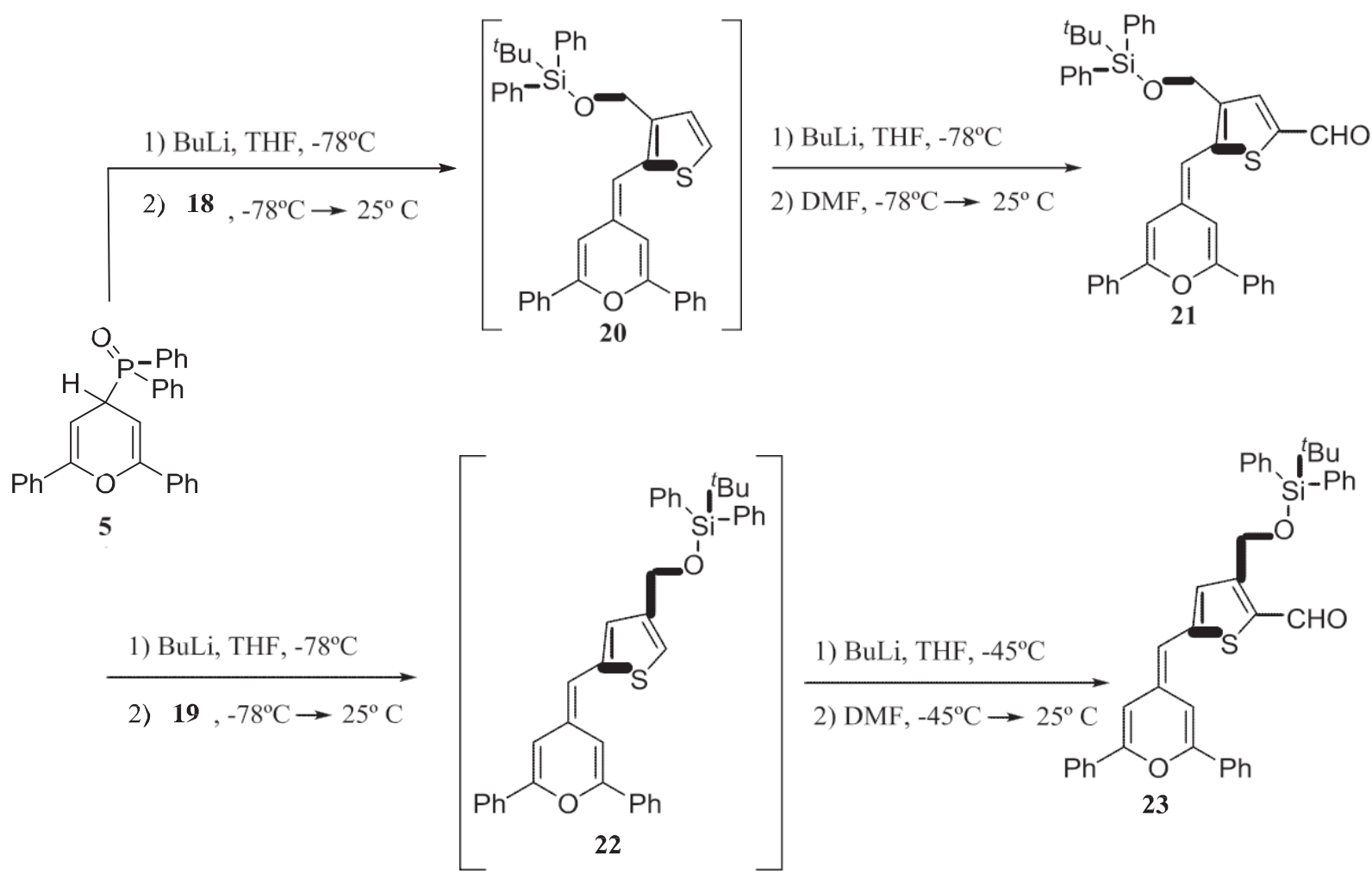

Scheme 6. Synthesis of aldehydes 21, 23.

charge. As it can be seen, the solar cells made using dye 15 have the slowest charge recombination under working conditions. Moreover, it is worthy to mention that a shift on the measured charge vs. voltage is observed for the solar cells made using dye 16 . This shift can be attributed to the lower coverage of dyes at the surface of the $\mathrm{TiO}_{2}$, which has as a consequence the lower concentration of protons at the surface of the $\mathrm{TiO}_{2}$. In fact, this is also in good agreement with the lower photocurrent measured.

\subsection{Theoretical calculations}

The electronic structures of the new synthesized compounds have been studied using density functional theory methods and the most relevant parameters derived from these calculations are gathered in Table 4. There is a good agreement with the

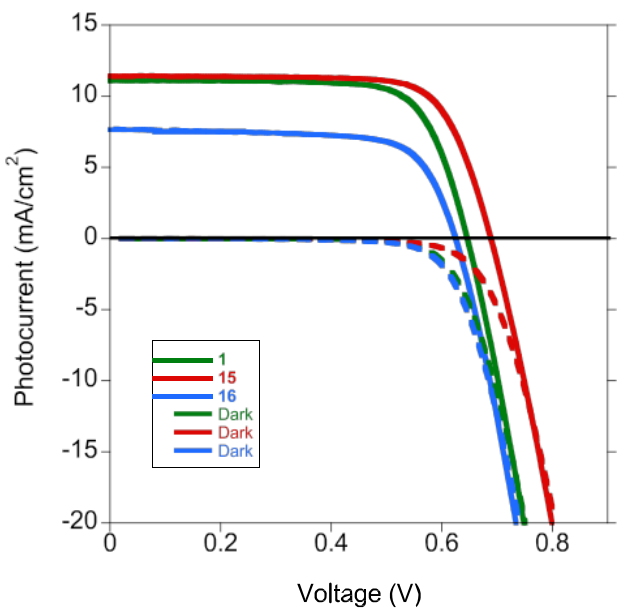

Fig. 5. JeV curves of compounds 1,15 and 16. experimental values described above, with estimated error of less than $0.25 \mathrm{eV}$ in the excitation energies, less than $0.1 \mathrm{~V}$ in $\mathrm{E}_{\mathrm{ox}}$ and less than $0.2 \mathrm{~V}$ in $\mathrm{E}_{\mathrm{ox}}^{*}$.

Calculations describe the first excited state as the consequence of a one-electron transition from the HOMO to the LUMO (see Fig. 7). Excitation involves some charge transfer from the donor to the cyanoacetic acid acceptor, with a large HOMOeLUMO overlap that gives rise to large oscillator strengths and therefore to great molar extinction coefficients.

Unfortunately, a direct correlation between the oscillator strengths (proportional to the peak area) and the molar extinction coefficients (related to peak height) is not possible for compounds giving rise to absorption bands of different width. Thus, compound 2 having the largest gives rise to the narrowest absorption band and also the lowest $\mathrm{f}$.

4H-pyranylidene compounds 1,15 and 16 display similar HOMO and LUMO energies and therefore their excitation energies and oxidation potentials are also similar. Compound 2, with a weak donor group has a lower HOMO energy compared to the other studied dyes and, therefore, displays higher excitation energies and EOX.

\section{Conclusions}

A series of five new metal free sensitizers (DepeA) for DSSC with a trialkylsilyl ether group in the spacer have been synthesized and characterized. Several donor unities have been studied,

Table 3

Photovoltaic properties of DSSCs constructed using the dyes 1, 15 and 16

\begin{tabular}{lllll}
\hline Dye & $\mathrm{J}_{\mathrm{sc}}\left(\mathrm{mA} \mathrm{cm} \mathrm{cm}^{-2}\right)$ & $\mathrm{V}_{\mathrm{oc}}(\mathrm{V})$ & $\mathrm{ff}$ & $\mathrm{h}(\%)$ \\
\hline 1 & 11.74 & 0.644 & 74 & 5.56 \\
15 & 11.44 & 0.689 & 74 & 5.86 \\
16 & 7.71 & 0.624 & 71 & 3.42 \\
\hline
\end{tabular}



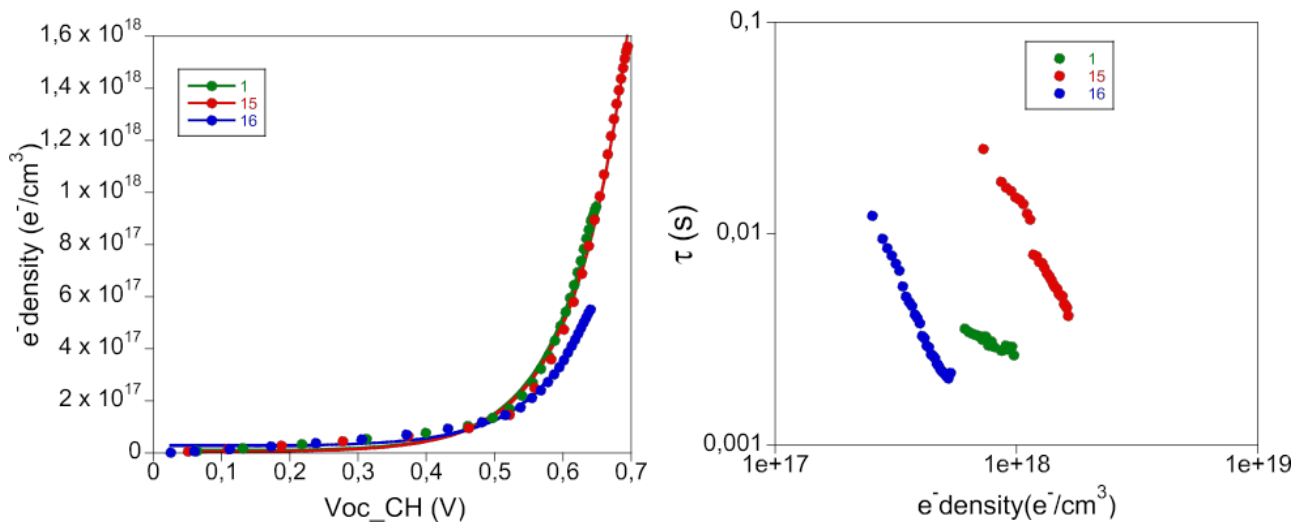

Fig. 6. Charge extraction (left) and transient photovoltage (right) curves of compounds 1,15 and 16 .

Table 4

Results of DFT calculations.

\begin{tabular}{|c|c|c|c|c|c|c|c|c|}
\hline & $\mathrm{E}_{\mathrm{HOMO}}(\mathrm{eV})$ & $\mathrm{E}_{\text {LUMO }}(\mathrm{eV})$ & $\mathbf{1}_{\mathrm{Abs}}(\mathrm{nm})$ & $\mathrm{f}^{\mathrm{a}}$ & $1_{\mathrm{em}}(\mathrm{nm})$ & $\mathrm{E}_{0-0}(\mathrm{eV})$ & $\mathrm{E}_{\mathrm{ox}}, \mathrm{V}$ (vs. NHE) & $\mathrm{E}^{*}$ oX, V (vs. NHE) \\
\hline 1 & -6.38 & -2.29 & 558 & 1.24 & 666 & 2.03 & 0.95 & -1.08 \\
\hline 2 & -6.38 & -2.13 & 528 & 1.00 & 605 & 2.18 & 1.00 & -1.18 \\
\hline 3 & -6.58 & -2.11 & 431 & 1.23 & 565 & 2.50 & 1.24 & -1.26 \\
\hline 15 & -6.39 & -2.30 & 559 & 1.23 & 666 & 2.03 & 0.93 & -1.10 \\
\hline 16 & -6.40 & -2.33 & 564 & 1.25 & 663 & 2.03 & 0.95 & -1.08 \\
\hline
\end{tabular}

${ }^{\text {a }}$ Oscillator strength.

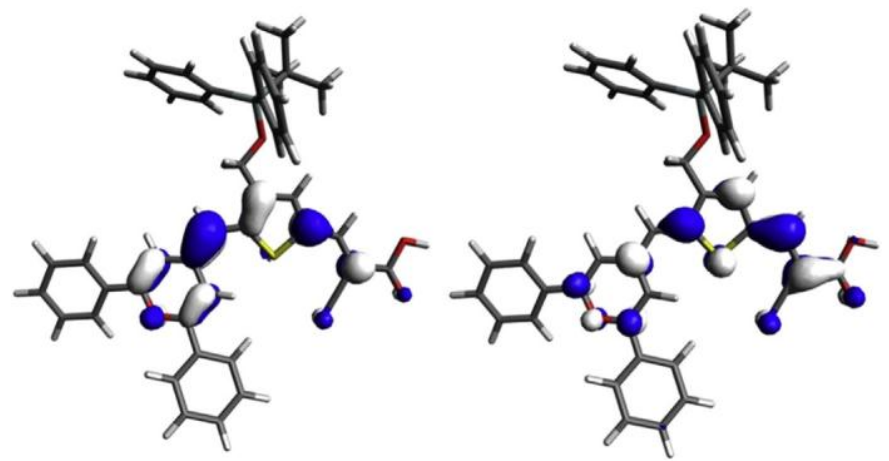

Fig. 7. HOMO (left) and LUMO (right) for compound 15.

obtaining the best performances with $4 \mathrm{H}$-pyranylidene, followed by triphenylamine (TPA) and dithiafulvene moieties respectively. Two trialkylsilyl ether groups (TBDMS and TBDPS) were compared in order to study the influence of their molecular size in the photovoltaic properties. The best efficiencies values were obtained for a TBDPS group at the position 4 of the thiophene ring. This observation indicates that trialkylsilyl ethers can be promising substituents for future more efficient sensitizers.

\section{Acknowledgments}

We gratefully acknowledge the financial support from the Spanish Ministry of Science and Innovation, MICINN-FEDER (project CTQ2011-22727), MINECO (project CTQ2014-52331-R) and the Gobierno de Aragón-Fondo Social Europeo (E39). A predoctoral fellowship to R. Pérez-Tejada (CSIC, JAE 2011) is also acknowledged. The authors thank Prof. Emilio Palomares for the use of the equipment at ICIQ and the helpful comments on the results. Dr. Laia Pelleja thanks MICINN for the Severo Ochoa Excellence Accreditation 2014.2018 (SEV-2013-0319).
Appendix A. Supplementary material

\section{References}

[1] Ragoussi M-E, Torres T. New generation solar cells: concepts, trends and perspectives. Chem Commun 2015;51:3957e72.

[2] Huang Y, Kramer EJ, Heeger AJ, Bazan GC. Bulk heterojunction solar cells: morphology and performance relationships. Chem Rev 2014;114:7006e43.

[3] Hagfeldt A, Boschloo G, Sun LC, Kloo L, Pettersson H. Dye-sensitized solar cells. Chem Rev 2010;110:6595e663.

[4] Hardin BE, Snaith HJ, McGehee MD. The renaissance of dye-sensitized solar cells. Nat Phot 2012;6:162e9.

[5] Mishra A, Fischer MKR, BGuerle P. Metal-free organic dyes for dye-sensitized solar cells: from structure:property relationships to design rules. Angew Chem Int Ed 2009;48:2474e99.

[6] Ning ZJ, Tian H. Triarylamine: a promising core unit for efficient photovoltaic materials. Chem Commun 2009:5483e95.

[7] Liang M, Chen J. Arylamine organic dyes for dye-sensitized solar cells. Chem Soc Rev 2013;42:3453e88.

[8] Tang J, Hua J, Wu W, Li J, Jin Z, Long Y, et al. New starburst sensitizer with carbazole antennas for efficient and stable dye-sensitized solar cells. Energy Environ Sci 2010;3:1736e45.

[9] Liang M, Lu M, Wang Q-L, Chen W-Y, Han H-Y, Sun Z, et al. Efficient dyesensitized solar cells with triarylamine organic dyes featuring functionalized-truxene unit. J Power Sources 2011;196:1657e64.

[10] Cai S, Hu X, Zhang Z, Su J, Li X, Islam A, et al. Rigid triarylamine-based efficient DSSC sensitizers with high molar extinction coefficients. J Mater Chem A 2013;1:4763e72.

[11] Bonnier C, Machin DD, Abdi OK, Robson KCD, Koivisto BD. The effect of donormodification in organic light-harvesting motifs: triphenylamine donors appended with polymerizable thienyl subunits. Org Biomol Chem 2013;11: 7011 e5.

[12] Wang Z, Liang M, Wang H, Wang P, Cheng F, Sun Z, et al. Joint electrical, photophysical, and photovoltaic studies on truxene dye-sensitized solar cells: impact of arylamine electron donors. ChemSusChem 2014;7:795e803.

[13] Kim SH, Choi J, Sakong C, Namgoong JW, Lee W, Kim DH, et al. The effect of the number, position, and shape of methoxy groups in triphenylamine donors on the performance of dye-sensitized solar cells. Dyes Pigm 2015;113:390e401.

[14] Franco S, Garín J, Martínez de Baroja N, Pẻrez-Tejada R, Orduna J, Yu Y, et al New D-peA-conjugated organic sensitizers based on 4H-pyran-4-ylidene donors for highly efficient dye-sensitized solar cells. Org Lett 2012;14:752e5. 
[15] Pẻrez-Tejada R, Pelleja L, Palomares E, Franco S, Orduna J, Garín J, et al. Novel 4H-pyranylidene organic dyes for dye-sensitized solar cells: effect of different heteroaromatic rings on the photovoltaic properties. Org Electron 2014;15: 3237 e 50

[16] Bolag A, Nishida J-i, Hara K, Yamashita Y. Enhanced performance of dyesensitized solar cells with novel 2,6-diphenyl-4H-pyranylidene dyes. Org Electron 2012;13:425e31.

[17] Gauthier S, Caro B, Robin-Le Guen F, Bhuvanesh N, Gladysz JA, Wojcik L, et al. Synthesis, photovoltaic performances and TD-DFT modeling of pushepull diacetylide platinum complexes in $\mathrm{TiO}_{2}$ based dye-sensitized solar cells. Dalton Trans 2014;43:11233e42.

[18] Guo K, Yan K, Lu X, Qiu Y, Liu Z, Sun J, et al. Dithiafulvenyl unit as a new donor for high-efficiency dye-sensitized solar cells: synthesis and demonstration of a family of metal-free organic sensitizers. Org Lett 2012;14:2214e7.

[19] Wan Z, Jia C, Duan Y, Chen X, Lin Y, Shi Y. Novel organic dye employing dithiafulvenyl-substituted arylamine hybrid donor unit for dye-sensitized solar cells. Org Electron 2013;14:2132e8.

[20] Wan Z, Jia C, Duan Y, Chen X, Li Z, Lin Y. Novel organic sensitizers containing dithiafulvenyl units as additional donors for efficient dye-sensitized solar cells. RSC Adv 2014;4:34896e903.

[21] Hara K, Dan-oh Y, Kasada C, Ohga Y, Shinpo A, Suga S, et al. Effect of additives on the photovoltaic performance of coumarin-dye-sensitized nanocrystalline $\mathrm{TiO}_{2}$ solar cells. Langmuir 2004;20:4205e10.

[22] Ren XM, Feng QY, Zhou G, Huang CH, Wang ZS. Effect of cations in coadsorbate on charge recombination and conduction band edge movement in dye-sensitized solar cells. J Phys Chem C 2010;114:7190e5.

[23] Choi H, Baik C, Kang SO, Ko J, Kang MS, Nazeeruddin MK, et al. Highly efficient and thermally stable organic sensitizers for solvent-free dye-sensitized solar cells. Angew Chem Int Ed 2008;47:327e30.

[24] Xu M. Zhang M, Pastore M, Li R, De Angelis F, Wang P. Joint electrical, photophysical and computational studies on DepieA dye sensitized solar cells: the impacts of dithiophene rigidification. Chem Sci 2012;3:976e83.

[25] Cai L, Tsao HN, Zhang W, Wang L, Xue Z, Gratzel M, et al. Organic sensitizers with bridged triphenylamine donor units for efficient dye-sensitized solar cells. Adv Energy Mater 2013;3:200e5.

[26] Shi J, Chai Z, Zhong C, Wu W, Hua J, Dong Y, et al. New efficient dyes containing tert-butyl in donor for dye-sensitized solar cells. Dyes Pigm 2012;95: 244 e 51.

[27] Zhan X, Barlow S, Marder SR. Substituent effects on the electronic structure of siloles. Chem Commun 2009:1948e55.

[28] Lu G, Usta H, Risko C, Wang L, Facchetti A, Ratner MA, et al. Synthesis, characterization, and transistor response of semiconducting silole polymers with substantial hole mobility and air stability. Experiment and theory. J Am Chem Soc 2008:130:7670e85.

[29] Akhtaruzzaman M, Seya Y, Asao N, Islam A, Kwon E, El-Shafei A, et al. Donoracceptor dyes incorporating a stable dibenzosilole p-conjugated spacer for dye-sensitized solar cells. J Mater Chem 2012;22:10771e8.

[30] Ko S, Choi H, Kang MS, Hwang H, Ji H, Kim J, et al. Silole-spaced triarylamine derivatives as highly efficient organic sensitizers in dye-sensitized solar cells (DSSCs). J Mater Chem 2010;20:2391e9.

[31] Lin LY, Tsai CH, Wong KT, Huang TW, Hsieh L, Liu SH, et al. Organic dyes containing coplanar diphenyl-substituted dithienosilole core for efficient dyesensitized solar cells. J Org Chem 2010;75:4778e85.

[32] Zeng WD, Cao YM, Bai Y, Wang YH, Shi YS, Zhang M, et al. Efficient dyesensitized solar cells with an organic photosensitizer featuring orderly conjugated ethylenedioxythiophene and dithienosilole blocks. Chem Mater 2010;22:1915e25.

[33] Minaev BF, Baryshnikov GV, Minaeva VA. Electronic structure and spectral properties of the triarylamine-dithienosilole dyes for efficient organic solar cells. Dyes Pigm 2012;92:531e6.

[34] Park J, Lee E, Kim J, Kang Y. Dithienosilole based organic sensitizers for efficient dye-sensitized solar cells. Bull Korean Chem Soc 2013;34:979e82.

[35] Wuts PGM, Greene TW. Protection for the hydroxyl group, including 1,2- and 1,3-diols. In: Greene's protective groups in organic synthesis. 4th ed. John Wiley \& Sons, Inc.; 2006.

[36] Zewdu T, Clifford JN, Hernandez JP, Palomares E. Photo-induced charge transfer dynamics in efficient $\mathrm{TiO}_{2} / \mathrm{CdS} / \mathrm{CdSe}$ sensitized solar cells. Energy Environ Sci 2011;4:4633e8.

[37] Frisch MJ, Trucks GW, Schlegel HB, Scuseria GE, Robb MA, Cheeseman JR, et al. Gaussian 09. Gaussian 09 revision A.02. Wallingford, CT, USA: Gaussian, Inc.; 2009.

[38] Barone V, Cossi M. Quantum calculation of molecular energies and energy gradients in solution by a conductor solvent model. J Phys Chem A 1998;102: 1995 e2001.

[39] Cossi M, Rega N, Scalmani G, Barone V. Energies, structures, and electronic properties of molecules in solution with the C-PCM solvation model. J Comput Chem 2003;24:669e81.

[40] Zhao Y, Truhlar DG. The M06 suite of density functionals for main group thermochemistry, thermochemical kinetics, noncovalent interactions, excited states, and transition elements: two new functionals and systematic testing of four M06-class functionals and 12 other functionals. Theor Chem Acc 2008; 120:215e41.

[41] Hariharan PC, Pople JA. Influence of polarization functions on MO hydrogenation energies. Theor Chim Acta 1973;28:213e22.

[42] Hanwell MD, Curtis DE, Lonie DC, Vandermeersch T, Zurek E, Hutchison GR. Avogadro: an advanced semantic chemical editor, visualization, and analysis platform. J Cheminf 2012;4:17.

[43] Abaev VT, Karsanov IV, Urtaeva ZK, Blinokhvatov AF, Bumber AA, Okhlobystin OY. Preparation and properties of (4H-pyran-4-yl)diphenylphosphine oxides. Zh Obshch Khim 1990;60:1012e9.

[44] Andreu R, Cerdán MA, Franco S, Garín J, Marco AB, Orduna J, et al. Decreased optical nonlinearities upon CF3 substitution on tricyanofuran acceptors. Org Lett 2008;10:4963e6.

[45] Posner GH, Li Z, White MC, Vinader V, Takeuchi K, Guggino SE, et al. 1a,25Dihydroxyvitamin D3 analogs featuring aromatic and heteroaromatic rings: design, synthesis, and preliminary biological testing. J Med Chem 1995;38: 4529 e 37.

[46] Leliege A, Le Regent C-H, Allain M, Blanchard P, Roncali J. Structural modulation of internal charge transfer in small molecular donors for organic solar cells. Chem Commun 2012;48:8907e9.

[47] Jen K-Y, Ma H, Liu S, Dalton LR. Nonlinear optical compounds and methods for their preparation [US20040135130A1]. 2004.

[48] Eisfeld A, Briggs JS. The J- and H-bands of organic dye aggregates. Chem Phys 2006;324:376e 84

[49] Khatuya H, Pulito VL, Jolliffe LK, Li X, Murray WV. Novel thiophene derivatives for the treatment of benign prostatic hyperplasia. Bioorg Med Chem Lett 2002; 12:2145e8.

[50] Mori SN, Kubo W, Kanzaki T, Masaki N, Wada Y, Yanagida S. Investigation of the effect of alkyl chain length on charge transfer at $\mathrm{TiO}_{2} /$ dye/electrolyte interface. J Phys Chem C 2007;111:3522e7. 